\title{
El culto de las reliquias en las Cantigas de Santa María de Alfonso X el Sabio*
}

\section{The cult of Relics in the Cantigas de Santa María by Alfonso X the Learned}

\author{
Mª LUISA MARTín ANSÓN**
}

\begin{abstract}
RESUMEN
El presente trabajo plantea un análisis del culto de las reliquias a través de algunas

Cantigas de Alfonso X el Sabio, en particular de las veneradas en santuarios franceses. Analiza algunas prácticas habituales en el contexto religioso y social del momento, y recoge los relatos de las fuentes literarias en que se basan. Asimismo, pone de manifiesto la devoción por las reliquias de la que participa el mismo monarca, encargando y guardando los propios relicarios de su capilla.
\end{abstract}

PALABRAS CLAVE

Cantigas de Santa María, Alfonso X el Sabio, reliquias, peregrinación.

\begin{abstract}
The following study examines the cult of relics through certain Cantigas of Alfonso $X$ the Learned, specifically those venerated in French sanctuaries. The study analyses certain practices that are common in the religious and social context of that age and traces the literary sources on which they are based. Also, it highlights the monarch's devotion to relics as he personally ordered and looked after the reliquaries of his own chapel.
\end{abstract}

\section{KEY WORDS}

Cantigas de Santa María, Alfonso $X$ the Learned, relics, pilgrimage.

El apasionante mundo de las reliquias, que condicionaron la vida durante la Edad Media, aparece magníficamente reflejado, como no podía ser de otro modo, en la obra que supone una de las fuentes más importantes para el conocimiento de la sociedad medieval, sus prácticas, sus preocupaciones, su actividad cotidiana, como son las Cantigas de Santa Maríaํ. Numerosísimos son los estudios que se han realizado, analizando los aspectos más diversos, tanto desde el punto de vista lingüístico, como artístico.

* Fecha de recepción del artículo: 2010-11-11. Fecha de aceptación del artículo: 2010-12-1.

** Departamento de Historia y Teoría del Arte (Universidad Autónoma de Madrid). C.e.: luisa.martin@uam.es.

1 Ver al respecto: GUERRERO LOVILLO, J., Las Cantigas estudio arqueológico de sus miniaturas. I. D. V., Madrid 1949; MENENDEZ PIDAL, G., La España del siglo XIII leída en imágenes, Real Academia de la Historia, Madrid, 1986. 
Aquí nos vamos a centrar en la consideración de algunas reliquias, depositadas en santuarios franceses, cuyas leyendas o textos escritos, además de revelarlos como centros de peregrinación, ponen de manifiesto algunas prácticas peculiares. Entre ellas destacaremos las denominadas tournées de reliquias, en las que a la práctica religiosa va unida la recaudatoria. Del mismo modo, pondremos de manifiesto la valoración de una reliquia, «el velo de la Virgen», determinante en la reconstrucción de la catedral del gótico clásico francés por excelencia, Chartres. Obviamente, las Cantigas no pueden por menos que hacerse eco de una de las epidemias más terribles del mundo medieval, el «fuego de San Marcial» o mal des ardents, que encontrará un instrumento de curación en la "Santa Candela» aportada por la propia Virgen. Asimismo, en las Cantigas se pone de manifiesto la duda ante la autenticidad de una reliquia (zapato de la Virgen de Soissons) y la incredulidad ante su poder benéfico.

Ciertamente, las peregrinaciones a los santuarios tenían una finalidad principal, la obtención de favores. Pero no hay que perder de vista que los caminos no sólo venían motivados por la existencia de reliquias, sino que también había imágenes milagrosas o milagreras que, aun cuando no contuvieran reliquias, también escuchaban y atendían las súplicas de los fieles. En definitiva, a través de los textos e ilustraciones de las Cantigas, asistimos a la unión de un culto ya existente en relación a las reliquias, en el que predominan tradiciones locales de las que el propio Alfonso X se considera venerador, con una nueva devoción a María.

\section{LAS RELIQUIAS}

Las reliquias, restos físicos y materiales de los santos $u$ objetos relacionados con ellos que, por analogía, se convierten en reliquias, son, en sí mismas, objetos pasivos, pero que se cargan de valor cuando entran en contacto con los fieles, siendo parte integrante de la vida cotidiana durante la Edad Media. De algún modo expresan la voluntad del santo al que pertenecen, son obligadas en los altares de las iglesias ${ }^{2}$, son necesarias en los tribunales para los juramentos, ayudan a conseguir la victoria en la batalla, emanan perfumes, o curan enfermedades.

Distintos nombres designan a las reliquias. Así, se conocen como pignora, brandea, sanctuaria, beneficia, palliola, y, además, en algunos textos de la Edad Media aparece la expresión «grandes reliquias» para designar aquellas que motivan una devoción particular, básicamente reliquias corporales ${ }^{3}$. Junto a los cuerpos y reliquias de los mártires, hay que destacar especialmente las reliquias carnales de Cristo y, por analogía, todos los instrumentos de la Pasión, en particular la ma-

2 El Canon Item Placuit del quinto Concilio de Cartagena (401) prescribe que todos los altares contendrán reliquias.

3 REAU, L. y COHEN, G., El Arte de la Edad Media y la civilización francesa, Ed. Mexico, 1956, p. 41. HERRMANN-MASCARD, N., Les reliques des Saints. Formation coutumiere d'un droit, Paris 1975, pp. 41-49. 
dera de la Cruz. En el caso de la Virgen, al no ser mártir y no haber realizado milagros en vida, y al haber subido al cielo, era muy difícil la presencia de restos corporales. Sin entrar en el estudio en profundidad del mundo que rodea a las reliquias, es preciso recordar que existen distintos tipos que, de algún modo, podrían establecerse jerárquicamente. Las reliquias reales, es decir los fragmentos de un cuerpo santo, se dividen en tres categorías: insignes (cráneo, fémur, tibia), notables (mano, pie) y menores (diente, costilla).

La gran demanda de reliquias llevó a que, desde finales del s. IV, las iglesias no consideraran como reliquias sólo los restos humanos sino que, a partir de ese momento, se incluyeron también las reliquias reales no corpóreas, reliquias indirectas (ex contactu), es decir los elementos que fueron utilizados o que habían estado en contacto con el santo: jirones del vestido, aceite o cera de las lámparas que alumbraban cerca de la urna, agua de una fuente dedicada al santo, su sepulcro, o los objetos encontrados santificados por su presencia prolongada cerca del mismo. Especialmente valiosos son los aceites y otras materias que tenían su origen en los huesos de los santos, y los líquidos obtenidos por vinage (líquidos resultantes de haber lavado los restos de los santos y reliquias con vino y plantas aromáticas, que son tenidos por medicinas capaces de curar las más graves enfermedades o librar de la posesión del demonio) $)^{4}$.

En buena lógica el relicario, como el sarcófago, al haberse beneficiado del contacto con las reliquias - o el cuerpo- del santo, se convierte él mismo en una reliquia y participa de la virtus del santo. Así, incluso vacío, puede ser objeto de devoción, como es el caso del Santo Sepulcro de Jerusalén. Se conoce el caso de que los viejos trozos de madera de una arqueta, sustituida por otra de orfebrería, se hayan distribuido como reliquias 0 , incluso, el caso de un relicario vacío que hace milagros como si el santo estuviera presente (Milagros de San Prudencio). Un caso frecuente es el de la bipolarización del culto, que se manifiesta por una parte en torno al relicario «lleno», y por otra en torno al relicario (o sarcófago) vacío.

Sin embargo, este estatuto sagrado conferido a veces al relicario vacío, a menudo es poco respetado, ya que la realización de un relicario tiene también una lógica económica; siempre es posible utilizar el metal o las piedras preciosas en caso de necesidad de liquidez. Si no se conocen casos de donación de relicarios vacíos, abundan los ejemplos de ventas: la legislación eclesiástica, en este caso, preverá que el comprador no pueda ser laico y, en todo caso, es recomendado retirar las reliquias del relicario antes de su venta ${ }^{5}$.

4 MARTÍN ANSÓN, Mª L., «Los continentes de los sagrado. Relicarios y orfebrería en el mundo medieval», Diversarum Rerum, 2, Ourense, (2007), pp. 51-99.

5 DIERKENS, A., «Du bon (et de mauvais) usage des reliquaires au Moyen Age», en Les reliques. Objets, cultes, symboles. Actes du Colloque International de l'Université du Littoral-Côte d'Opale (Boulogne-sur-Mer) 4-6 septembre 1997, El E. Bozoky y A.M. Helvetius. Brepols. Publishers, (1999), pp. 239252. 
Por todo ello, monasterios, catedrales e iglesias se disputaban la posesión de reliquias, cuanto más significativas mejor, siendo a veces cuestionables los métodos de obtención. Ello fomentaba los hurtos y propiciaba la saturación del mercado, no siempre con garantía de autenticidad ${ }^{6}$. Su veneración favorecía, además, la Translatio de restos de santos, especialmente célebres por sus virtudes y milagros. A veces, el procedimiento era simplemente el hurto, producido de las más variadas formas y con el consentimiento de los contemporáneos que escuchaban los relatos y los consideraban manifestaciones de auténtica virtud cristiana. Así, el pío latrocinio, practicado con diferentes pretextos, pretendía obtener la protección que emanaba de las reliquias. Recordemos al propio obispo Gelmírez quien, según relato de la Historia Compostelana que tiene todas las características de una narración hagiográfica de robo de reliquias, en su viaje pastoral (1102) a una serie de iglesias dependientes de la diócesis de Santiago, en Portugal, observa que algunas reliquias de santos no están bien cuidadas y decide trasladarlas a Compostela, fraguando un plan, durante la noche, por inspiración divina ${ }^{7}$. En otras ocasiones, se llevaba a cabo una petición a monasterios o iglesias poseedores de determinadas reliquias para que les cediesen algunas, aunque si una reliquia se daba espontáneamente o se regalaba no se apreciaba tanto como si era robada.

Este afán por la posesión de reliquias facilitó su tráfico y falsificación. A pesar de que, a partir del siglo IX, las reliquias debían ir provistas de autentificación mediante tiras de pápiro o de pergamino, el mercado se inundaba, por ejemplo, de nuevos fragmentos de la Vera Cruz. Todo ello llevó a que el Papa Inocencio III, en 1215 , según se verá más adelante, prohibiera la veneración de reliquias que no tuvieran certificación de autenticidad. Curiosamente, a los traficantes de reliquias falsas se les denominaba «perdonadores» 0 «buleros». En la «Farsa de los Perdonadores», un monje presenta ante la multitud absorta la cresta del gallo que cantó en casa de Pilatos cuando San Pedro negó a Cristo, la mitad de un tablón del Arca de Noé y un guijarro del Paraíso ${ }^{8}$.

El perdonador era un vendedor de indulgencias o de bulas que ayudaban a las almas a acortar el tránsito hacia el cielo desde el purgatorio y que, en algunos casos, perdonaba todos sus pecados. Llevaba variedad de artículos en su bolsa, tales como una funda de almohada supuestamente de la Virgen, un fragmento de vela usada por Pedro como pescador, una cruz dorada de latón con piedras y huesos, que pasaba por ser de oro, así como huesos que hacía pasar por reliquias de santos $^{9}$. Sin duda, el «Cuento del bulero o del perdonador» de Geoffrey Chaucer

\footnotetext{
${ }^{6}$ Ver al respecto; GEARY, P. J., Furta Sacra. La trafugazione delle reliquie nel Medioevo (secoli IX$X I)$. Milan 2000.

7 DOMÍNGUEZ, M., "Gelmírez y el Fvrtvm Sacrvm» en Santos, Obispos y Reliquias. Actas del III Encuentro Internacional Hispania en la Antigüedad Tardía. Octubre de 1998 Acta Antiqva Complvtensia, 3. Universidad de Alcalá, (2003), p. 161.

8 REAU, L. y COHEN, G., Op. Cit., p. 43.

9 ROJO, B. R., Poemas y poetas clásicos ingleses. De G. Chaucer a Dylan Thomas. Antología bilingüe. 2005, p. 61.
} 
(1386-1400) supone una de las mejores sátiras de esta práctica. La presencia de «perdonadores» que llegaban de Roma, portadores de una carta con el sello pontificio que les daba derecho a perdonar los pecados y a conceder indulgencias a quienes les comprasen reliquias, lleva a Chaucer a mostrar al «perdonador» predicando un sermón sobre el tema: Radix Malorum Cupiditas ${ }^{10}$ (la raíz de todos los males es la codicia), declarando que no predica sino por codicia, y vende a los campesinos el derecho de besar las reliquias: ".... Después relato historias y extraigo bulas de papas, de cardenales, de patriarcas y de obispos, y pronuncio algunas palabras en latín para sazonar mi sermón y estimular la devoción de las gentes. Y sin más saco mis urnas de cristal, llenas de trapos y huesos, que los demás imaginan ser reliquias. Y tengo engastado en latón, el brazuelo de una sacra oveja judía... »11. Este tipo de prácticas, sin duda, debió estar muy extendido, teniendo un extraordinario reflejo en la literatura. A este respecto, no hay que olvidar que el quinto amo del Lazarillo de Tormes era un bulero estafador que peleó con un alguacil que afirmaba que sus bulas eran falsas.

No obstante, desde fechas tempranas surgieron críticas agudas en el seno de la propia iglesia que, con frecuencia, no fueron entendidas ni compartidas. Destacados autores se alzaron con el fin de combatir estas prácticas Así, el hecho que motivó la ejecución de una de las obras trascendentales en el conocimiento del mundo de las reliquias, De pignoribus sanctorum, de Guibert de Nogent (105355/1121-25), fue la pretensión de los monjes de Saint Medard de Soissons de poseer un diente de leche de Cristo. En los libros que componen la obra, Guibert se muestra muy crítico, entre otras cosas, con la veneración de falsas reliquias. Son estas denuncias, a veces vehementes, lo que le han llevado a ser considerado un precursor de Calvino (autor él mismo de un Tratado de Reliquias) ${ }^{12}$.

10 Pasaje de la Primera Epístola de San Pablo a Timoteo, 6-10: Radix enim omnium malorum est cupiditas: quam...

11 CHAUCER, G., Cuentos de Canterbury, Ed. Planeta, 1984, pp. 174-185.

12 PLATELLE, H., en Les reliques. Objets. Cultes. Symboles. Actes du Colloque International de I'Université du Littoral-Côte d'Opale (Boulogne-sur-Mer) 4-6 septembre 1997, E. Bozoky y A.M. Helvetius. Brepols. Publishers, (1999). El prefacio de la obra menciona tres partes, aunque en realidad hay 4, lo que plantea un problema cronológico en el que, evidentemente, no vamos a entrar. En el Libro I: trata de los abusos (errores) concernientes a los santos, las reliquias y los milagros.

1. De los verdaderos Santos: Guibert comienza por distinguir entre las verdades de la fe y los usos piadosos recomendados, pero no impuestos por la iglesia. Descarta a todos los santos dudosos y a todos de los que no conoce ni la fecha de su nacimiento, ni su vida, ni la fecha de su muerte, rehusando escribir sus «vitae». "¿Cómo podría yo decir cosas verdaderas sobre personajes que nadie ha visto jamás?»; esta frase resume su postura.

2. De los verdaderos milagros: Es necesario un examen crítico previo antes del culto oficial dirigido a un santo. El control compete a la autoridad religiosa. Los milagros no son siempre signos de santidad. A través de varios ejemplos plantea que, a veces, un milagro no atestigua la santidad de una persona sino que aporta solamente una prueba de la misericordia de Dios. Otras veces, hay milagros que recompensan una vida santa. "Hemos aportado estos milagros no a causa de su novedad, sino para dar razón de la diversidad de sus causas».

3. De las verdaderas reliquias: Guibert denuncia el origen evidente de gran cantidad de abusos y confusiones. Entre otras, cuenta la historia de Eudes, obispo de Bayeux (†1097), medio hermano de Guillermo el Conquistador que deseaba tener el cuerpo de S. Exuperio, su predecesor, objeto de culto en 


\section{LOS RELICARIOS}

Por otra parte, aunque las reliquias eran el verdadero tesoro con un valor intrínseco independiente del receptáculo que las contenía, curiosamente, ya desde el origen se valoran en comparación con los materiales que les servirán de envoltorio. Uno de los testimonios más antiguos, el del Martirio de San Policarpo, fechado hacia 155, se expresa del siguiente modo: «De esta forma pudimos recoger después sus huesos, más nobles que las costosas piedras preciosas y más estimables que el oro y los hemos colocado en un lugar conveniente...». Además, las propiedades que emanan de las reliquias parecen trasmitirse a los contenedores en que se guardan, y por ello San Juan Crisóstomo (†407) decía : «abracemos sus relicarios, los relicarios de los mártires pueden tener un gran poder como sus propios huesos» ${ }^{13}$.

Así, el respeto y la veneración que generaban las reliquias determinó la creación de objetos de gran valor para custodiarlas, y éstos acabaron por apropiarse de un término que les pertenecía sólo por extensión, de modo que reliquias y relicarios formaban un todo, una unidad inseparable. Además de proteger y honrar una determinada reliquia, el relicario cumple también otros cometidos importantes. Debe hacer visible su presencia, bien mostrándola directamente o bien a través de símbolos; mediante referencias iconográficas o evocando su forma, mientras las ins-

Corbeil (cerca de Paris). Gratificó con una suma de cien libras de dinero al sacristán de esta iglesia para obtener el santo en cuestion; pero este guardián desenterró el cuerpo de un campesino del mismo nombre y lo llevó al obispo. El prelado le preguntó bajo juramento que si era el cuerpo de San Exuperio y el respondio: "Yo puedo jurarte que es el cuerpo de Exuperio, pero yo no diré nada de su santidad, pues muchas gentes que llevan este nombre han dejado una reputación bien alejada de la santidad». El obispo fue así tranquilizado por la declaración equívoca del ladrón.

Guibert hace una distinción entre los responsables del culto y las gentes sencillas, sin instrucción. Las reglas en materia del culto a los santos no son las mismas. Para los primeros es una falta y una locura autorizar o practicar un culto dudoso. Los «simplices», "rudes», si toman un santo por otro poco importa, pues todos los santos forman con Cristo un cuerpo místico viviente del que Él es la cabeza.

El Libro II: Trata de la Eucarístia, la «única» que asegura la presencia espiritual de Cristo en nuestro mundo. Considera faltas de base las pretensiones de algunas iglesias por poseer reliquias corporales de Cristo, a menudo extrañas, y a veces indecentes. Cristo no ha podido dejar tales reliquias, porque "ha querido ejercitar nuestra fe y hacernos pasar de su cuerpo original a su cuerpo místico e instruirnos en la inteligencia de la simplicidad divina".

En el Libro III: sobre esta base sólida pasa a la refutación de las pretensiones de los monjes de San Medard de Soissons con extremada vivacidad. No duda en tratarlos de "falsarios» y pregunta ¿qué hay más estúpido que proclamar lo que no se puede apoyar en argumentos?

El Libro IV: probablemente compuesto antes que los otros, en unión con un comentario del Génesis, sirve de coronamiento. Después de haber mostrado en los tres primero libros el camino hacia un culto puro y auténtico de las reliquias y los santos, Guibert examina las cosas más altas y quiere indicar el camino hacia Dios, el Creador de todas las cosas. El autor tiene un sentido muy claro de la distinción de lo espirítual y de lo material. El primer eco puede percibirse por los sentidos, si no mediante imágenes tomadas de nuestro mundo sensible. Esta posición es muy diferente de la «visión medieval» habitual que mezcla los dos mundos en un todo continuo con los mismos caracteres.

En los Libros II y III recurre, como los escolásticos, a la técnica de las objeciones (7 en el libro II y 6 en el III). Esta presentación anuncia la estructura de la Summa Theologica de Santo Tomás, pero en este siglo XII, traduce, sobre todo, la influencia de San Anselmo.

13 S. Juan Crisóstomo, De ss.Bernice et Prosdoce, 7, P.G.: t. L, col. 640, col. 576, Cf. N. HERRMANN-MASCARD, Op. Cit., pp. 23 y 29. 
cripciones incisas en él, identifican el contenido. Por otra parte, hay que señalar que las funciones del relicario, paradójicamente, son antagónicas pues implican la exhibición y la protección; la conservación y la exaltación y procesión, así como la presentación de lo sensible, pero también la representación de lo inteligible. Eran receptáculos encargados de proteger y exhibir, transportar y activar los restos materiales. El gran liturgista del siglo XIII Guillermo Durando, en su Rationale divinorum officiorum, remonta su clasificación fundada sobre una razón a la vez espiritual y material ${ }^{14}$.

Desarrollando las funciones de envoltura y protección, los relicarios fueron primeramente un medio de conservación durante el traslado, o de defensa contra los pillajes. Además, era necesario defender los restos de los santos de una piedad excesiva, así como, en determinados momentos, de posibles saqueos a causa de incursiones de pueblos extraños, especialmente en los siglos IX y X. En el ámbito español, la invasión musulmana propició numerosos traslados de restos de mártires hacia el norte, siendo uno de los más significativos el de San Isidoro, para quien se realizó un magnífico relicario. Depositarios de los restos santos, mediadores entre los creyentes y lo sagrado, los relicarios medían las etapas en los caminos de peregrinación.

A causa del valor de los materiales en que se realizaban, suponían también un signo de ostentación y riqueza, y lo que en un principio se planteaba como una fiesta de las reliquias, que eran mostradas al pueblo, en realidad se convertía en una exposición del tesoro que guardaba esas reliquias y era susceptible de incrementarse con donaciones de procedencias diversas, como joyas de coronación, pendientes, brazaletes de oro o piedras preciosas, que los enriquecían.

Hasta el siglo XIII no hay instrucciones precisas para la exposición de las reliquias. Será Inocencio III quien, en 1215, imponga severas normas al respecto, prohibiendo la veneración pública de nuevas reliquias sin aprobación pontificia y la exposición de las reliquias fuera de su contenedor: «Ne reliquie uenales ostendantur uel noue uenerentur. De reuerentia reliquiarum. Ne reliquie sanctorum extra capsam nec moueantur in ueneratione sine Romana ecclesia... Ne noue reliquie uenerentur sine licentia pape.... De indulgentia et ueneratione reliquiarum ${ }^{15}$.

Estas prohibiciones y la concesión de indulgencias a la veneración de los relicarios sin duda fomentarán su creación, agudizada por la avalancha y dispersión de reliquias producida con ocasión, especialmente, de la cuarta cruzada. El auge se produce sobre todo a partir del siglo XIII, con una tendencia a transferir sis-

${ }^{14}$ BRAUN, J., s.j. Die Reliquiare des christliche Kultes und ihre Entwicklung. Freiburg-im-Breisgau, 1940.

15 Constitutiones Concilii Quarti Lateranensis una cum comentariis contenedor glossatorum, Ed. A. García y García, Cittá del Vaticano 1981, c.62, p.168-169. POTTHAST, A., Regesta Pontificum Romanorum ab condita ecclesia ad annum post Christum natum MCXCVIII ad A. MCCCIV. Berolini 1874, vol. I, p. 438. El pasaje de la constitución cum ex eo canon 62 será incluido en los Decretales en 1234. 
temáticamente los cuerpos y reliquias de los santos a nuevos contenedores. Es posible, además, que los espléndidos relicarios traídos de Constantinopla por los Cruzados después de 1204 hayan suscitado una emulación en Occidente.

\section{LAS CÁMARAS DEL TESORO}

Aún partiendo de la idea de que la iglesia en su conjunto era considerada lugar de conservación normal de las reliquias, si dejamos de lado el hecho de que las reliquias se empotraban en columnas y capiteles a fin de que los santos «habitasen» en toda la iglesia, son, en principio, las criptas y los nichos de los altares, lugares propios para su conservación. Se cita al respecto a San Eloy (†659), que hizo elevar una serie de construcciones sobre las tumbas que se encontraban detrás de los altares y que, de algún modo, son el antecedente de las arquetas que se levantarán después. Los diferentes tipos de «altares de reliquias» concebidos en esta época primitiva realizan una estrecha unión entre el altar y la tumba que, pese a todo, siguen siendo distintos. Con el aumento de altares durante la Alta Edad Media, aumenta el número de reliquias ${ }^{16}$.

En la época cristiana primitiva, la costumbre había nacido de levantar altares e iglesias sobre la tumba de los mártires. En el s. IV comienza la traslación de reliquias a fin de que las iglesias que no poseen reliquias propias las tengan igualmente. El sepulcro, la cripta y la Confessio juegan un papel cada vez mayor. Se confeccionan capsae y scriniae preciosas para el transporte de las reliquias y su conservación, incluso en el exterior de la tumba. Lo mismo que para los cálices, los libros y las vestimentas litúrgicas, estaba prevista una especie de armarios en lugares seguros; de ahí las cámaras del tesoro y las cámaras de reliquias. Sin embargo, la importancia que la Edad Media concede a las reliquias condiciona el arte de los tesoros y la aparición de cámaras del tesoro ${ }^{17}$.

En los inventarios medievales, reliquias y relicarios, junto a los objetos necesarios para la celebración del culto (vasos sagrados en metal precioso o en piedras duras, ciborios, cálices y sus patenas, cruces, incensarios, manuscritos, tapas de encuadernación, vestimentas litúrgicas....), forman parte del Ministerium, constituyendo la otra categoria el Ornamentum, que reúne los elementos utilizados para adornar el edificio (frontales de altar, candelabros, etc.).

Así, pues, con frecuencia el número creciente de los objetos reunidos ha justificado la creación de un lugar específicamente organizado para guardarlos. Llamada en los planos Thesaurus, Sacrarium, Armorium, cámara o casa del tesoro, cámara de oro (Aurea Camina) en Colonia, este espacio estaba, generalmente, situado en la parte alta, junto al deambulatorio, con el cual comunicaba por un es-

16 RONIG, F. J., «Tresors et Chambres de reliques», en Rhin-Meuse. Art et Civilisation 800-1400. Cologne-Bruxelles, 1972, pp. 134-135.

17 GRABAR, A., Martyrium. Recherches sur le culte des reliques et l'art chrétien antique. Paris, 1946. 
trecho vano. Su acceso es, a menudo, deliberadamente difícil, como en Bayeux, donde era preciso recurrir a una escalera para deslizarse por un óculo en la sala abovedada que conservaba el tesoro, construida encima del revestiario de los canónigos. La disposición es muy próxima en Albi, Sens, Orleans o Saint Jean de Maurienne. El mobiliario litúrgico corriente depositado en la sacristía se conocía como «Pequeño Tesoro»; el otro era el «Gran Tesoro» ${ }^{18}$.

\section{LAS PEREGRINACIONES}

Aunque de modo somero, es necesario hacer una mención a las peregrinaciones. El culto de las reliquias ${ }^{19}$ será determinante en su desarrollo y, al igual que ellas, consustancial a la humanidad, si bien en el occidente cristiano adquiere especial relevancia a partir de los siglos VIII-IX, momento en que se desarrolla un ingente comercio 20 .

Así, pues, las reliquias, tesoro espiritual y fuente de riqueza, dominaban la vida doméstica y religiosa, la vida cultural, jurídica, política, económica y artística. La posesión de reliquias importantes y célebres propiciaba la afluencia de devotos que, movidos por la fe, trataban de obtener determinados beneficios. Es obvio que significaban una fuente de ingresos de primer orden, e incluso, en momentos puntuales de necesidad, se llevaban fuera de las propias fronteras para obtener recursos económicos con los que acometer o finalizar determinadas obras. Desde el siglo IX las peregrinaciones serán frecuentes, tanto a santuarios y monasterios próximos, como a otros lugares - Santiago, Roma o Tierra Santa-que implican un largo viaje. Los siglos XII y XIII serán los de mayor esplendor.

Alfonso X, tomando como referencia el Fuero Real (Libro IV, título 24, ley 1), explicita en las Partidas $(I, 23)$ el derecho que asiste a los peregrinos de ser guardados y defendidos en su viaje. E insistiendo en su preocupación por favorecer a los peregrinos que pasen por sus reinos, el 6 de noviembre de 1254 expidió un valioso privilegio garantizando su protección, así como su libertad de testar, para posteriormente, en una carta expedida el 29 de noviembre del mismo año, instar a los concejos y autoridades del Camino de Santiago para que pongan en cumplimiento, en sus localidades, el privilegio otorgado el día 6 de noviembre. Toda esta normativa se contiene, con pequeñas modificaciones, tanto en la Nueva Recopilación $(\mathrm{I}, 12,1)$ como en la Novísima Recopilación ${ }^{21}$.

18 SIRE, M. A., "Les Trésors de cathedrales: salles forte, chambres aux reliques ou cabinets de curiosités?», en 20 Siecles en Cathedrales, 2001, p. 193.

19 Hay que recordar que las reliquias como tales no son objeto de culto, a excepción de la Santa Cruz. Es el santo que representan materialmente quien es objeto de este culto. LEMAîTRE, J. L., «Les reliques et leur culte en Limousin aux XIle. et XIIle. siècles", en L'Oeuvre de Limoges. Art et histoire au temps des Plantagenêts. Actes du colloque, musée du Louvre, 1995, Paris, 1998, p. 143.

${ }_{20}$ CABROL, F. y LECLERQ, H., Dictionnaire d'Archeologie Chretienne et de Liturgie, Paris 1948, t. 14, $2^{\text {a }}$ part., col. 2294-2359.

${ }^{21}$ PARDO GATO, J. R., «El derecho castellano-leonés en la peregrinación jacobea. Una reflexión histórico-jurídica», Revista jurídica de Castilla y León, № 5, enero 2005, p. 202. 
En esta concatenación de hechos, la obtención de milagros se convierte en uno de los objetivos prioritarios del viaje, de modo que las reliquias, signos vivos y palpables de Dios, desempeñan un papel básico, la realización de milagros. Dios continúa revelándose a los hombres mediante prodigios. De este modo, peregrinación, veneración de reliquias y súplica para la obtención del milagro se integran en una práctica piadosa. A través de ellas se presentaba lo santo al pueblo en forma visible y como una fuerza que actuaba mágicamente. Según la doctrina de San Gregorio Nacianceno, el que toca o venera los huesos de un mártir participa de la virtud y la gracia que reside en ellos.

\section{ALFONSO X Y EL CULTO DE LAS RELIQUIAS}

Estas mínimas reflexiones previas sirven para ubicar parte del contexto religioso en que se desarrolla la vida del Rey Sabio. No obstante, hay todavía que resaltar un aspecto fundamental del que participan todos los integrantes de la sociedad medieval, desde distintas vertientes, como es el culto a María. Durante el siglo XIII, los milagros de la Virgen dominan la devoción europea, mediante la intervención o no de sus reliquias indirectas. A pesar de que Ella, según se ha señalado, fue asunta a los cielos y, por tanto, su cuerpo no puede ser venerado directamente, nos ha dejado trozos de su vestido, mechones de su pelo o zapatos que obran milagros.

Así, pues, la devoción a María, en cuyo contexto hay que insertar la elaboración de las Cantigas, es uno de los rasgos más característicos de la espiritualidad de los siglos XII y XIII. En los distintos códices se recogen numerosos milagros llevados a cabo por su intercesión, atendiendo a las súplicas de los devotos que acuden ante Ella. Entre estos aparecen reflejados algunos sucesos, recogidos en la literatura medieval, acaecidos fuera de territorio hispano, en santuarios, especialmente franceses, donde se guardan reliquias de primera magnitud. Numerosos relatos, quizás los de mayor antigüedad, nacen en dichos santuarios y sirven para la difusión de los acontecimientos milagrosos que, desde épocas anteriores, se recogen y se van transmitiendo.

Como señala A. Carrera de la Red, en su momento, la finalidad de estas colecciones era eminentemente práctica. Se suceden los resúmenes de milagros tomados de ellas para intercalarlos en los manuales de los predicadores junto a mitos y leyendas de la Antigüedad, convenientemente moralizados, y cuentos y romances populares o ejemplos de la historia natural, porque los rustici y los simplici, así como los monachi, necesitan exempla edificantes cuando se les habla de la conversión, la contrición, el arrepentimiento o la gracia. Parece evidente que el escritor cree en los milagros; los ha oído contar y los recoge para mayor gloria de Dios y de su Madre, y como incentivo para los que tienen el espíritu algo abandonado. La posibilidad de que los hechos no ocurriesen realmente se descarta, y la 
doctrina del cómo ocurrieron se considera de más. Cuando entiende que la credibilidad de los milagros puede resultar difícil a quien los escucha, salva la dificultad recordando a los lectores el poder omnímodo de Dios y de su Madre, y subrayando ante los posibles objetores la necesidad de dar a las mentes sencillas una explicación plástica de las cosas divinas ${ }^{22}$.

Las colecciones que relatan milagros locales aparecen ya en el siglo $\mathrm{X}$, alcanzando su auge en la duodécima centuria, mientras que las de carácter más general, entre las que ocupa lugar destacado la obra de Gonzalo de Berceo, que recogen milagros marianos ocurridos en todos los tiempos y lugares, inciden menos en la valoración de la reliquia y apuntan ya en una nueva dirección, que considera prioritaria la salvación del alma. En ocasiones se recurre también a colecciones locales de milagros marianos, si bien en estos casos el lugar pierde su importancia y muchas veces es simplemente omitido; porque el objetivo no es tanto fomentar las peregrinaciones como la piedad personal ${ }^{23}$.

A Hugo Farsito, canónigo regular de Saint Jean des Vignes, en Soissons, se debe la relación de milagros denominada Libellus de miraculis Beatae Mariae Virginis in urbe Suessionensi, cuyos episodios, en número de treinta y uno, van de 1102 a 1131, año este último en el que se produjo la visita de Inocencio II a Soissons. La redacción, sin embargo, no se llevó a cabo hasta después de 1143, fecha de la muerte de la abadesa Matilde. Compañero de San Bernardo, su obra fue muy difundida por los cistercienses ${ }^{24}$. La colección se menciona en la Cantiga 61: "Dest'un miragre vos direi que aveo / en Seixons, ond'un livro a todo cheo I de miragres, ben d'i, ca d'alhur non veo, que a Madre de Deus mostra noit'e dia».

Igualmente hay que destacar la obra De miraculis Beatae Mariae Virginis, de Gualterio de Compiègne (monje cluniacense), o el Liber de miraculis sanctae Dei genitricis Mariae, atribuido a Pothon (fraile benedictino de mediados del siglo XII). Asimismo, sabemos que Alfonso X poseía un ejemplar del Speculum Historiale, de Vicente de Beauvais ${ }^{25}$. El latín se combinará con el empleo de las lenguas romances y muchas de estas colecciones se traducirán ${ }^{26}$. En este sentido, destaca la obra de Gautier de Coincy (1177-1236), que constituye la primera colección vernácula continental conservada. Poeta, músico y prior en el monasterio de Soissons, es autor de dos volúmenes titulados Les miracles de la Sainte Vierge, compuestos entre 1218 y 1231 , con cerca de treinta mil versos, escritos en francés medieval, en

22 CARRERA DE LA RED, A., «Creencia y Literatura en los Miracula Beatae Mariae Virginis (s. XIII)», Cuadernos de Filología Clásica. Estudios latinos no 14, U.C.M., 1998, pp. 149-165 (p. 154).

${ }^{23}$ BAYO, J.C., «Las colecciones universales de milagros de la Virgen hasta Gonzalo de Berceo», Bulletin of Spanish Studies, vol. LXXXI, no 7-8, (2004), pp. 849-871.

24 FARSITUS, H., «Libellus de miraculis Beatae Mariae Virginis in urbe Suessionensi», en Patrologiae cursus completus: series Latina, Ed. Jacques-Paul Migne, CLXXIX, 1855, 1773-1800, p. 1774.

25 Se recoge en su testamento, como regalo de San Luis, ALFONSO X, Antología. Ed. de Solalinde, Madrid, 1977, p. 236.

26 Ver, entre otros, MARTIN, J. L., «los milagros de la Virgen: versión latina y romance», en Espacio. Tiempo y Forma, Serie III, Historia Medieval, t. 16 (2003), pp. 177-213. 
los que se relatan más de cincuenta milagros ${ }^{27}$. Asimismo, nos interesa destacar el encargo realizado a Jean Le Marchant, canónigo de Peronne, por parte del obispo de Chartres Matthieu des Champs (1247-59), para llevar a cabo la adaptación en verso a la lengua vernácula de Le Livre des miracles de Notre Dame de Chartres ${ }^{28}$. De este modo se trataba de hacer llegar su conocimiento a una población más amplia.

Este movimiento literario tuvo su repercusión en tierras hispanas y, así, el confesor y amigo de Alfonso X, fray Juan Gil de Zamora ${ }^{29}$, compuso en latín el Liber Mariae, en el que recoge relatos anteriores, y Gonzalo de Berceo, en romance castellano, los Milagros de Nuestra Señora ${ }^{30}$. El monarca, conocedor de estos y otros relatos de acontecimientos acaecidos en los santuarios más famosos, que circulaban por Occidente, nos deja en las Cantigas un exponente de su religiosidad y devoción a María. Entre ellos, es evidente que no podían faltar aquellos que recogían el entusiasmo por el culto de las reliquias, del que el propio monarca participa, a quien veremos recogiendo sus propios relicarios. Así, pues, en las Cantigas que analizaremos, la reliquia es la principal protagonista y los episodios contados están especialmente relacionados con milagros locales ocurridos en tierras francesas.

Entre los santuarios, fue internacionalmente famoso en el culto mariano el monasterio de Rocamador, mencionado con gran insistencia por Alfonso X. Las gentes acudían allí atraídas por la figura de Santa María y, también, por encontrarse en el lugar un cuerpo, milagrosamente conservado, de un ermitaño, descubierto en 1166, llamado desde entonces San Amador. Junto con Santiago de Compostela, eran los lugares más visitados por los peregrinos, su apogeo en el siglo XIII fue extraordinario. Allí acudieron, como peregrinos, el propio monarca francés Luis IX y su esposa Blanca de Castilla ${ }^{31}$. Asimismo, Arras, con la Santa Candela; Chartres, con el velo de la Virgen, y Soissons, donde se conservaban las zapatillas de María, son objeto de atención. Centrándonos en estos últimos santuarios y en las reliquias en ellos contenidas, vamos a recoger algunas de las prácticas más significativas asociadas a ellas.

27 COINCY, Gautier de, Les miracles de Notre Dame, ed. V.F. Koening, Genève 1966-1970, 4 vols. Una selección de los milagros en COINCI, Gautier de, Los Milagros de Nuestra Señora, ed. J. Montoya Pérez, Barcelona, 1989.

28 Le MARCHANT, J., Le Livre des Miracles de Notre Dame de Chartres. Écrit en vers au XIIle. siècle. Preface, glossaire et notes par M. G. DUPLESSIS, Chartres, 1885, (Hay ediciones posteriores, entre ellas la de Pierre Kunstmann, Publications Médievales de I'Université de Ottawa, I, Ottawa, 1973. No obstante, se utilizará la de 1885).

${ }_{29}$ GIL DE ZAMORA, J. (O.F.M.), Milagros de Santa María del «Liber Mariae», Ed.. Francisco Rodriguez Pascual, Zamora, Semuret, 2007.

${ }^{30}$ Entre las numerosas ediciones, recogemos, GONZALO DE BERCEO, Los Milagros de Nuestra Señora, Ed. García Turza, Logroño, 1997.

31 GARCÍA CUADRADO, A., Las Cantigas: El Códice de Florencia, Murcia, 1993, pp. 19-20. 


\section{LAS TOURNÉES DE RELIQUIAS}

A pesar de que Alfonso $X$ es explícito en Las Partidas, disponiendo que las reliquias no se sacasen de aquellos lugares o estudiesen para mostrarlas con cobdicia de ganar con ellas algo $0^{32}$, como en otras ocasiones, las Cantigas recogen testimonios de lo que las Partidas prohíben; así, un buen ejemplo de las denominadas Tournées de reliquias está presente en la Cantiga no 35 (Mss. El Escorial).

La utilización de las reliquias con fines recaudatorios no es algo nuevo de estos momentos, sino que se trata de una práctica antigua ${ }^{33}$. Sin embargo, el comienzo de una llamada a percibir contribuciones, basada en la ostentación de reliquias y destinada a financiar una cantera en construcción, se definió, al parecer, en la parte norte de Francia hacia mediados del siglo XI, en el ámbito monástico, antes de atraer la atención de los obispos que pensarán en reglamentarla en el Concilio de Poitiers de 1110. El Concilio decidió que los clérigos que la realizaran llevando reliquias con ellos, no estarían autorizados a predicar. El primer ejemplo, atestiguado por un relato de Drogon de Bergues, concierne a las reliquias de Santa Lewine, desplazadas en 1058 por los monjes de Bergues-Saint-Winoc ${ }^{34}$.

Esta ostentación y culto de las reliquias, unido a su «explotación» económica como bienes rentables, es lo que tradicionalmente se conoce como Tournées de Reliques, costumbre que suponía procesionar con las reliquias por distintos lugares con el fin de recaudar fondos para fines benéficos, tales como llevar a cabo la fábrica de la catedral. Ni siquiera órdenes tan austeras como el Císter en sus inicios escaparon a esta práctica. De este modo, vemos cómo en 1195 un abad es condenado a una penitencia de seis días, uno de ellos a pan y agua, por haber, dice el Estatuto, «enviado un monje y un converso a mendigar con reliquias», y la colecta fue confiscada en beneficio del Capítulo General. Una vez más, la sanción impuesta indica la vulneración de la norma ${ }^{35}$.

Sin embargo, antes de entrar en el análisis del relato de Cantiga $n^{\circ} 35$, tal vez convenga preguntarse cómo se organizaban estas tournées. No hay una situación tipo pero, a través de algunas fuentes y documentos iconográficos, se pueden evitar algunas ideas preconcebidas como la de que un material de reemplazo sustituía a las preciosas arquetas donde se solían conservar las reliquias. La mayoría de los datos señalan que eran los propios relicarios los que se trasladaban (Laon, 1221;

\footnotetext{
${ }^{32}$ ALFONSO X EL SABIO, Las Siete Partidas. Versión José Sánchez-Arcilla. Madrid 2004. Partida I, titulo IV, ley CXXI.

${ }^{33}$ BUENACASA PÉREZ, C., "La instrumentalización económica del culto a las reliquias: una importante fuente de ingresos para las iglesias tardoantiguas occidentales (ss. IV-VIII) «en Santos, Obispos y Reliquias. Actas del III Encuentro Internacional Hispania en la Antigüedad Tardía. Octubre de 1998. Acta Antiqva Complvtensia, 3. Universidad de Alcalá, 2003, p. 133.

${ }_{34}$ PRESSOUYRE, L., «Reliques et cathedrales gothiques, le cas de France», en 20 siècles en Cathedrales, 2001. p. 113

${ }_{35}$ MARTÍN ANSON, Mํㅡ. L., «El tesoro sagrado de los monasterios cistercienses hispanos: entre la austeridad y la opulencia», Monasterios Cistercienses en la España Medieval. Aguilar de Campoo, 2008, pp. 182-213.
} 
Arras, 1328 y 1338 , sendos inventarios dan cuenta de una arqueta de plata dorada y un cáliz-relicario, etc.). Estos objetos preciosos excitaban, evidentemente, a los codiciosos que, a veces, secuestraban o torturaban a los recolectores de la catedral. Los relicarios viajaban prácticamente sin protección.

En la época heroica de la institución, los desplazamientos se hacían a pie; más tarde se emplean carretas. Cuando estas carretas son citadas en los textos (en 1333 en Amiens, en 1451 y 1484 en Saint Quentin), parecen haber sido utilizadas para el traslado de los cofres entre dos etapas. Los documentos concernientes al viaje de reliquias de la catedral de Noyon en 1463 precisan que el capítulo compró tres caballos para el transporte de los dos cofres-relicarios que contenían las reliquias, y cuatro campanillas destinadas a anunciar a la población la llegada de los recaudadores. Sobre el terreno, el cortejo debía cambiar de apariencia y los representantes del capítulo llevaban en andas las reliquias, como se ve en la mayoría de las representaciones, en las que la presencia de un tiro de animales es excepcional. Se dirigían entonces hacia la iglesia, depositando las arquetas sobre el altar y, teóricamente al menos, dejaban predicar al clérigo local, ya que el Concilio de Poitiers de 1110 prohibió la predicación a los clérigos ambulantes ${ }^{36}$.

La prohibición había sido reiterada por numerosos sínodos diocesanos y provinciales. Después, promulgada por el canon 62 del IV Concilio de Letrán de 1215 , incidía en la prohibición a los clérigos «ambulantes» de tomar la palabra sin autorización especial del Papa o del Obispo y restringía los sermones a los asuntos expresamente especificados en estos documentos. Además, ordenaba a los recaudadores viajar con un equipaje modesto, llevar hábitos de acuerdo a su estado y no alojarse en posada ${ }^{37}$. Sin embargo, hay que señalar que la norma no fue respetada casi nunca.

La Cantiga número 35 (figs. 1 y 2): «Esta es cómo Santa María hizo que se quemase la lana de los mercaderes que habían ofrecido algo a su imagen, y se lo cogieron luego", nos deja un magnífico ejemplo de esta práctica ${ }^{38}$. El episodio co-

36 PRESSOUYRE, L., Op. Cit., pp. 178-179.

37 HEFELE y LECLERCQ, Histoire des Conciles, t. V, 2 ${ }^{\mathrm{a}}$ parte, p. 1695.

${ }^{38}$ ALFONSO X, EL SABIO, Cantigas de Santa María, Códice Rico de El Escorial versión de José Filgueira Valverde, Ed. Castalia, Madrid 1985.

CANTIGA 35, Mss. El Escorial, pp. 69-72: «De este asunto, diré un hermoso milagro que hizo la Virgen María, que es Señora de gran prez, por unas reliquias suyas, que llevaron, en cierta ocasión, unos clérigos de Francia, de lo que os quiero contar. // Estos eran de la ciudad que se llama León del Ródano, en que había entonces una gran iglesia que ardió de tal manera que se convirtió en carbón, pero (el fuego) no tocó a las reliquias; esto debéis creerlo. //

Porque había allí leche de la Virgen espiritual, y además cabellos, envueltos en un cendal, todo ello en un arca hecha de oro, no de otra cosa; aquí no tocó el fuego, lo demás ardió todo. //Los clérigos cuando vieron que la iglesia, como os digo, se había quemado, hubieron de acordar que se fuese, por el mundo, con las reliquias, a ganar para que su iglesia pudiese ser rehecha pronto. //Maestre Bernardo tenía por nombre uno de ellos, que era deán, hombre manso y de muy buen talante, que se afanaba siempre por ganar el Paraíso; éste es el que fue con las reliquias para darlas a conocer. // Y anduvo primero Francia - como tengo sabido- donde hizo Dios muchos milagros por medio de ellas, y fue así, como des- 
rresponde a la colección de milagros de la catedral de Laon, donde se recogen dos salidas de reliquias, organizadas por el obispo Bartolomé para recaudar fondos para la construcción de la nueva catedral, después del incendio sufrido en 1112, a causa de una revuelta popular que terminó con la vida de su antecesor, el obispo Gualdrico. Relata el incendio sufrido en la catedral de Laon, del que salieron ilesas las reliquias (leche y cabellos de la Virgen, entre otras), y cómo los clérigos, entre ellos el deán, maestre Bernardo, viajaron con ellas, sufriendo diversos contratiempos, incluido un ataque de piratas. Mercaderes navegantes conducirán las reliquias salvadas por la intervención de María.

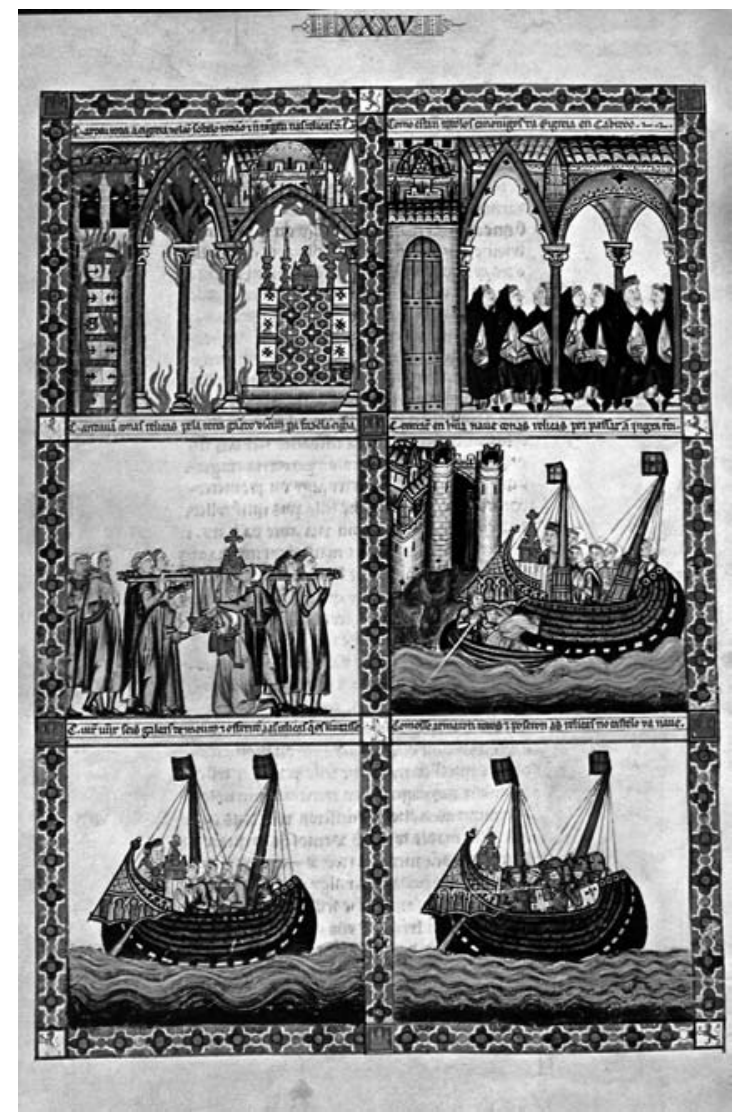

Fig. 1. CANTIGA 35 (Mss. El Escorial).

pués, a Inglaterra y para llevarlas más en salvo, fue a meterlas en la nave // de un mercader que tenía por nombre Colistanus, que los llevase a Bretaña, la que pobló el rey Brutus, y entró tanta gente que no cabían más allí más; muy ricos mercaderes que llevaban grandes haberes. // Iban ya por el mar, todos muy a su placer, y tuvieron un gran susto, pues vieron que seis galeras se aproximaban a ellos, a todo correr. // de corsarios que hacían muchos daños en aquel mar. Y cuando el señor de la nave les vio, dijo:

-"No me place estos que aquí vienen, pero formémonos en haz y pongamos en alto las reliquias, donde pueda verlas."// 


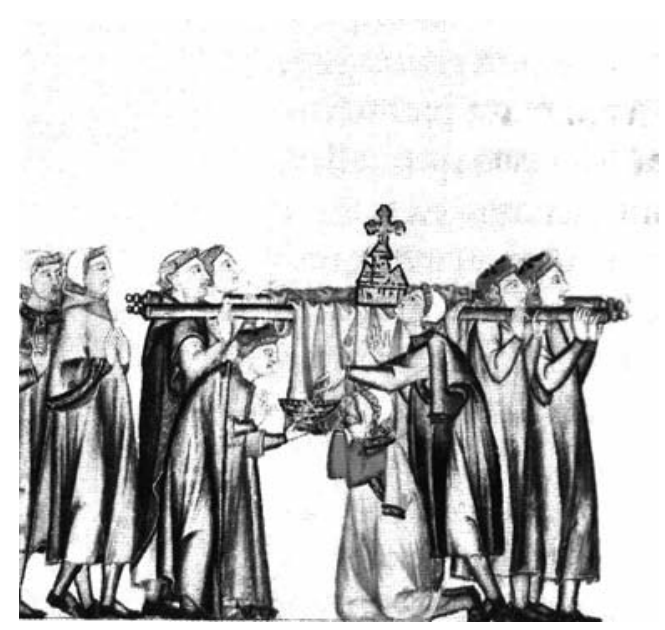

Fig. 2. Det. CANTIGA 35 (Mss. El Escorial).

Luego que esto dijo, maestre Bernardo sacó el arca con las reliquias, y, en cuanto las mostró, no quedó ninguno de cuantos mercaderes iban en la nave que no viniese a hacer una oferta valiosa. // Todos, en aquel momento, muy de grato ofrecían, y mucho; unos daban paños, otros dinero, diciendo:

-"Señor, toma todo esto, no dejo nada, sólo queremos que nos guardes los cuerpos de la muerte y de mala prisión." /l.

A todo esto, las seis galeras no dejaban de acercarse, cada una por su parte, para atacar la nave. $Y$ el que tenía el arca de las reliquias - sin mentir-, la alzó hacia el cielo y fue a ponerlas en alto. // El almirante de las galeras venía muy delante de su gente y el que tenía el arca de la Virgen Madre de Dios les dijo con grandes voces:

-"Falsos, malos e incrédulos, nosotros somos de Santa María, aquella de la que Cristo quiso nacer, // y, por ello, no nos hagáis mal, si no luego morirás tú y, con cuantos traes contigo, te irás al infierno y de cuanto piensas hacer nada acabarías, porque estas reliquias quieren defender de ti esta nave." /I

Cuanto el clérigo decía, lo tuvo el almirante por vil, e hizo tirar desde las galeras más de mil saetas para matar a los de la nave, pero un viento no sutil se levantó en seguida que hizo volverse a las galeras, // que a la del almirante la hendió de arriba abajo y quebró el mástil y sobre él cayó, dándole tan gran herida que los ojos le sacó fuera de la cabeza y lo hizo caer al mar. // Y aquel viento del sur hizo alejarse tanto a las galeras que no se vieron ya por ninguna parte, y se diviso Dover, que pobló al rey Artur, y entonces todos se supieron a salvo, // y luego hacia las reliquias, corriendo, vino un gran tropel de aquellos mercaderes, y cada uno tomó su fardel con cuanto había prometido, sin parar mientes en el bello y maravilloso milagro con que los había salvado // la Virgen Santa María, Madre del muy alto Rey, que mató a sus enemigos, como os he dicho. Y maestre Bernal les dijo:

"Haré con vosotros un trato: os daré la mitad y dejaréis quedar lo demás." //

Todos respondieron en seguida:

"No habrá otro trato sino que nos llevamos todo, y de aquello que ganáramos cada uno dará lo que le convenga como pueda permitirse." //

Los más de aquellos mercaderes eran de Flandes y de París, y cuando se apartaron, cada uno de ellos quiso comprar lana con sus ganancias, creyendo que podrían llevarla a salvo a su tierra. // Y cuando la hubieron comprado, un día, antes de amanecer, salieron del puerto de Dover; pero, el que murió en la Cruz, queriendo vengar a su Madre, hizo como aquel que presenta gran poder para meter miedo, para que se corrigiesen// del gran tuerto que habían hecho a su Madre Emperatriz, que es Señora del Mundo. Y para ello -ipor san Félix! - que hirió un rayo la nave y, como dice el escrito, quemó toda aquella lana y no tocó en ninguna otra cosa. // Cuando este milagro vieron, volvieron muy de grado a donde dejaran las reliquias y dijeron:

-"Pues Dios quiere que demos de lo nuestro a su Madre, cada uno dará lo que tuviere buenamente, id a recibirlo." //

Dijo maestre Bernardo: 
El caso de Laon es uno de los ejemplos más conocidos, gracias a dos relatos prácticamente contemporáneos de los acontecimientos: el de Guibert de Nogent y el de Hermann de Laon, ex-abad de San Martin de Tournai. Se realizaron dos viajes: el primero inmediatamente después de un incendio de la catedral en abril de 1112; y el segundo, del 28 de marzo al 6 de septiembre de 1113, que fue menos tranquilo, escapando a los piratas, y es el que se recoge aquí. Alfonso $\mathrm{X}$ recibe el relato de la tradición escrita, iniciada en el libro De miraculis $S$. M. Lauduniensis de Hermann de Laon, pero confunde esta localidad con «León do Rodano». Versificado por Gautier de Coincy en Le Miracle de la Fièrte de Laon, aparece también en Gil de Zamora.

La accidentada historia de estas reliquias codiciadas y milagrosas hace pasar piratas, mercaderes y navegantes de un mar de agitadas olas a un gran puerto, y, finalmente, a una iglesia de Nuestra Señora, donde sobre el altar está entronizada una imagen de la Virgen ${ }^{39}$. Los episodios se suceden en dos columnas que se leen de arriba abajo: a) Se muestra la iglesia en llamas. Sobre el altar, dos candelabros, una cruz y la arqueta relicario. b) Los canónigos, reunidos, acuerdan que se vaya por el mundo con las reliquias para «ganar dineros» y rehacer la iglesia. c) El deán se pone en marcha llevando procesionalmente las reliquias, y los fieles se aproximan dejando su limosna. d) Embarcan las reliquias en la nave de un mercader llamado Colistanus, en dirección a Bretaña; al frente va el deán, Maestre Bernardo, y cuando iban ya por el mar vieron aproximarse seis galeras con corsarios. e) Maestre Bernardo sacó el arca de las reliquias y la puso en alto, y todos los mercaderes que iban en la nave hicieron sus ofrendas, pidiendo salir ilesos del ataque. A pesar de las palabras de recriminación al almirante de las galeras, diciéndole que las reliquias protegerían la nave y ellos morirían e irían al infierno, el almirante mandó lanzar más de mil saetas para matar a los de la nave. Pero se levantó tal viento que obligó a volverse a las galeras, el mástil cayó sobre el almirante sacándole los ojos y tirándole al mar, se divisó Dover, y todos se sintieron a salvo. Entonces, los mercaderes fueron a recuperar las ofrendas que habían hecho a la Virgen, sin valorar el milagro. Maestre Bernardo les propuso que se llevasen sólo la mitad, pero no aceptaron, diciendo que se lo llevaban todo y después, con las ganancias, cada uno daría lo que pudiera permitirse. La mayoría de los mercaderes eran de Flandes y París, y cada uno quiso comprar lana con sus ganancias para llevarla a su país, pero un rayo cayó sobre la nave y quemó la lana. Arrepentidos, fueron a hacer ofrendas donde dejaron las reliquias y Maestre Bernardo convino en aceptar sólo un tercio. f) Se armaron todos y pusieron las reliquias sobre el castillo de la nave.

-"Esto es muy justo, que os acordéis de las reliquias de la Virgen que con Dios se asienta a la que hicisteis gran tuerto, faltando a vuestra promesa."

Y no quiso más que un tercio, que hizo luego recoger».

39 GAUTHIER, M. M., Les routes de la foi. Reliques et reliquaires de Jerusalem à Compostelle, Fribourg 1983. p. 102. 


\section{CURACIÓN DEL ORFEBRE QUE HABÍA REALIZADO LA ARQUETA RELICARIO}

Íntimamente vinculada a ésta, la Cantiga 362 (Códice de Florencia, fig. 3) nos cuenta la historia del orfebre, artífice de la arqueta que contuvo las reliquias durante esta travesía, y cómo recuperó la vista gracias a la intervención de María: "Como Santa María hizo recobrar la vista a un orfebre de Chartres» 40 .

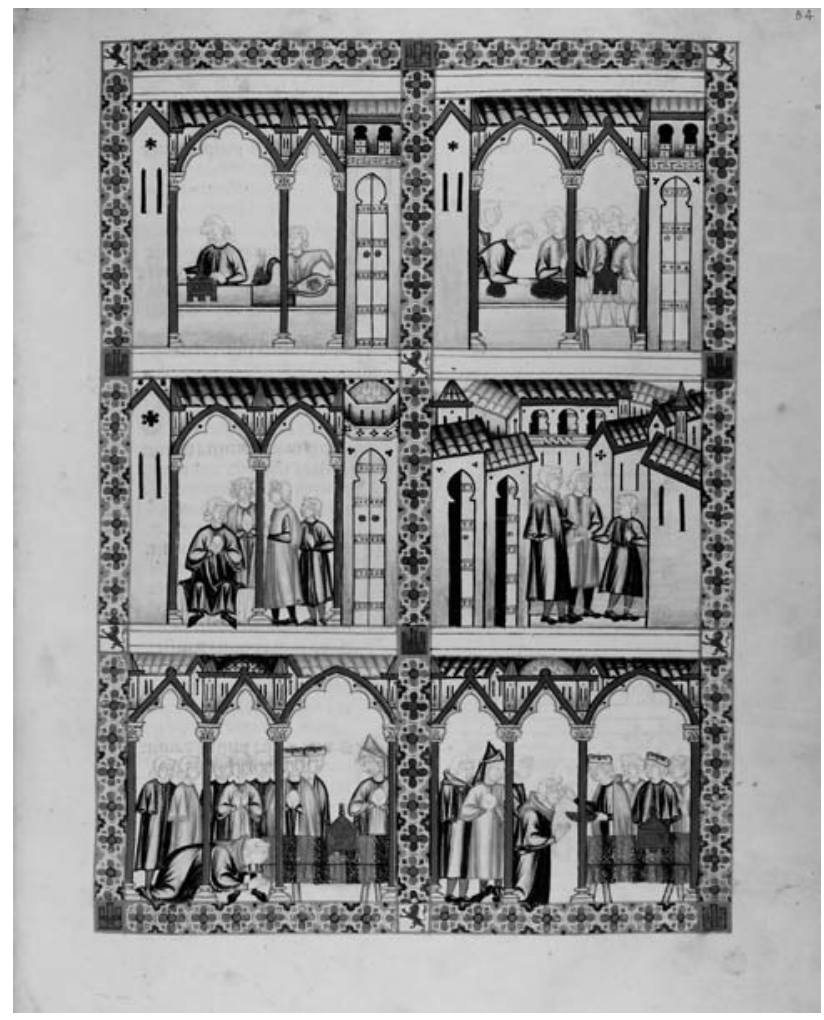

Fig. 3. CANTIGA 362 (Cod. Florencia).

40 Alfonso o Sabio. Cantigas de Santa Maria. Ed. crítica de Walter METTMANN, t. II, pp. 284-285: "Como Santa María fez cobrar seu lume a un ourivez en Chartes Ben pode Santa Maria / seu lum' ao çego dar, / pois que dos pecados pode / as almas alumear. «E de tal razon com'esta / vos quer'eu ora dizer / un miragre mui flemoso / que foi en França fazer / a Virgen Santa Maria, / que fez un çego veer /be nena vila de Chartes, / como vos quero contar. / Estribillo. / Este çeg'ourivez fora / que non ouvera meIlor/ en todo o reyno de França / ne-nas terras arredor, e en servir sempr' a Virgen / avia mui gran sabor; / e porend' hua arca d'ouro / fora mui rica lavrar / Estribillo / Pora trager as reliquias / sempre ena preçisson. / E poren vende-la fora /ena See de Leon / e dera dela por algo / e dela dera en don, / pois que soube que avian / as reliquias y andar. / Estribillo / Esta foi aquela arca / de que vos eu ja falei/ que tragian pelo mundo / por gaar, segund'achei / escrito, porque ss' a vila / queimara, como contei/ outrossi, e a ygreja / toda senon o altar. / Estribillo / U estas reliquias eran. / E tan toste manaman / as fillou logo correndo / un que era y dayam / e levou-as pelas terras / e soffreu mui grand' affan / por gaar con elas algo / con que podessen cobrar/ Estribillo / La ygreja que perderan. / E grandes miragres fez / por elas San- 
El arca donde Maestre Bernardo llevaba las reliquias había sido adquirida en Laon y era obra del orfebre ciego al que curó la Virgen: «Este orfebre ciego que no hubiera mejor en todo el reino de Francia y en las tierras de alrededor, servía siempre a la Virgen e hizo un arca de oro ricamente labrada para llevar reliquias. Y la vendió fuera, en See de Leon (Laon). Esta fue aquella arca de que ya he hablado que llevaban por el mundo para ganar, según he escrito, porque se había incendiado una iglesia toda, excepto el altar donde estaban las reliquias. Y llevólas por las tierras sufriendo gran afán por ganar con ellas algo con que pudiesen cobrar. Andando así por las tierras llegaron a Chartres donde aquel orfebre que era ciego, después de oír como estaba hecha el arca, dijo que él la había hecho perdiendo la vista. Fue ante el arca, se postró llorando y del agua con que lavaron el arca se limpió el rostro y vio mucho mejor que antes, dando gracias a la Virgen».

A través de las distintas viñetas se ilustra la historia referida, que acaba, como se ha dicho, con el orfebre recuperando la vista. Es interesante subrayar que nos deja un importante testimonio de una de las actividades mejor consideradas en el ámbito medieval, la de orfebre. Incluso, siguiendo clasificaciones de las artes de la época, observamos que era considerada como la principal. Así, vemos al orfebre en su taller dando los últimos toques a la arqueta y, a su lado, otro personaje avivando el fuego mediante un fuelle.

\section{EL VELO DE LA VIRGEN DE LA CATEDRAL DE CHARTRES}

Desde tiempos muy antiguos, uno de los centros de culto mariano clave en el mundo medieval era Chartres. La capilla, situada en el deambulatorio norte, expone la reliquia conocida como el Velo de la Virgen (fig. 4). Esta capilla lleva también el nombre de Capilla de los Mártires, a causa de las cinco vidrieras narrativas que cuentan la vida y el martirio de varios santos, entre ellos, san Esteban y san Vicente.

El velo de la Virgen fue ofrecido por los emperadores bizantinos a Carlomagno, y trasmitido a Carlos el Carlos, quien lo donó a la Catedral de Chartres hacia el 876. La tradición le confiere el papel de salvaguarda de la ciudad. A esta reliquia vino a sumarse la cabeza de Santa Ana, regalo del Conde de la Región, con posterioridad a los acontecimientos de 1194, que conducirían a la construcción de la gran catedral que hoy conocemos.

ta Maria, / como vos dix outra vez; / ca eran y sas reliquias / desta Sennor de gran prz, / e queria Deus por elas / grandes miragres mostrar. / Estribillo / Andando asi per las terras. / a Chartes ouvieron d'ir/ $u$ aquel ourivez era / çego; e pois foy oyr/ de arca com'era feita, / disso logo sen falir: / <Par Deua, eu fiz aquela arca / ante que Fosse çegar.> / Estribillo / E mandou-sse levar logo / alá a omees seus, / dizendo: <Se alá chego, / ben ei feuza en Deus / e $n$ asa Madre beeyta / que veerei destes meus / ellos, que por meus pecados / muit' á sse foron serrar.> / Estribillo / E poi que foi ant' a arca, / se deitou e lle pediu / merçee muito chorando; / e da agua que sayu, / con que a arca lavaran, / trouxe pelo rostr' e viu / mui mellor que ante vira. / E fillou-ss' a braadar, / Estribillo / Chamando < Santa Maria, / Madre de bon Rey Jesu, / porque vejo dos meus ollos / beeyta sejas tu; / e pois m'este ben feziste, / quando me for mester, u / teu Fillo sever julgando, / queyras por mi razoar.> / Estribillo». 


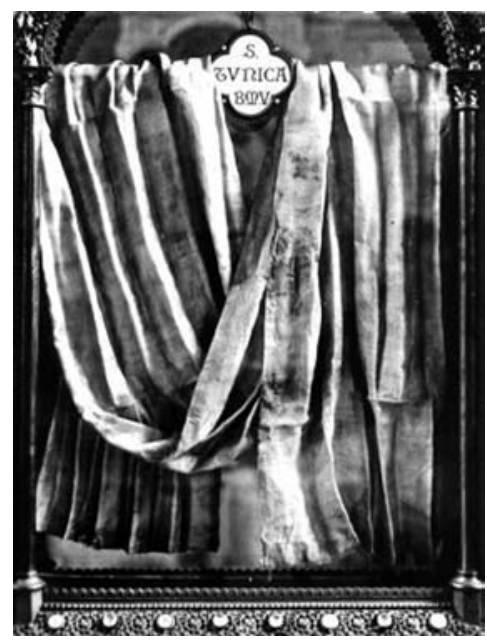

Fig. 4. RELIQUIA DEL VELO DE LA VIRGEN. Catedral de Chartres.

Después de algunos incendios que llevaron a remodelar iglesias anteriores, en especial la catedral románica, en 1194, de nuevo, el fuego arrasa por completo (excepto el pórtico occidental, conocido como Pórtico Real), la fábrica de la catedral. La ciudad queda sumida en la más profunda tristeza, puesto que se cree que en el incendio ha desaparecido el Velo de la Virgen, reliquia que la protegía. El hecho se interpreta como una señal de la ira divina, y el desánimo lleva a plantearse la no reconstrucción de la catedral. La presencia de Melior de Pisa, nombrado por Celestino III como legado papal, será determinante para instar al clero y al pueblo. Durante el transcurso de una ceremonia religiosa, una procesión porta el Velo de la Virgen que se había salvado al estar depositado en la cripta. Este hecho cambia el estado anímico de la población, que pasa del desaliento a la euforia. De pronto, en Chartres se creyó que la propia Virgen había permitido la destrucción de la antigua basílica porque deseaba que se construyera en su honor una nueva y más bella iglesia, y la reconstrucción de la catedral se convierte en el gran objetivo. Todos estos acontecimientos los conocemos mediante una fuente cronológicamente próxima, Le livre des miracles de Notre Dame de Chartres, escrito por un clérigo hacia 1210 , cuando ya la nueva catedral estaba en marcha, y traducido del latín y puesto en verso (en torno a 6.400 versos), en lengua vernácula, según se ha señalado, por Jean le Marchant en 1262, época de Luis IX y su esposa la reina Blanca, a petición del obispo Macé (Mathieu). Según manifiesta el propio autor en el prólogo, fue la piedad hacia Notre Dame de Chartres lo que le impulso a la empresa ${ }^{41}$. Como puede observarse, estamos ante una muestra más del poder de una reliquia, gracias a la cual hoy podemos contemplar la catedral del gótico clásico francés por excelencia.

41 Le MARCHANT, J., Op. Cit., Miracle Troisième; «De larsure de liglise de Chartres et comment li legas sarmona aus gens de la ville», pp. 17-32. 
La extraordinaria reliquia, durante mucho tiempo conservada en una arqueta cerrada, ha llevado el nombre de la «Santa Camisa». La apertura de esta arqueta en el siglo XVIII permitió constatar que se trata de un velo de seda. Se muestra en un relicario del siglo XIX, en cobre dorado. Esta preciosa reliquia favoreció el desarrollo de numerosas peregrinaciones desde la Edad Media hasta la Revolución francesa. Bajo el impulso de Charles Péguy, quien peregrinó en 1912, las peregrinaciones han retomado su interés de modo creciente.

La Cantiga 148 (Mss. El Escorial, figs. 5 y 6), además de la visita al santuario donde estaba depositada la reliquia, recoge los beneficios que emanan de ella e impregnan los objetos que entran en contacto con la misma. Narra cómo las telas tocadas por la camisa (velo) de la Virgen, Carnotum camisia, tienen el poder de hacer que quienes vistan prendas confeccionadas con ellas no puedan ser heridos por sus adversarios. Se trata del relato del milagro 21, según la citada obra de Jean le Marchant $^{42}$. En él se cuenta cómo un caballero que, en una peregrinación a Notre Dame de Chartres, había hecho tocar sus camisas con la de la Virgen, no pudo ser herido ni vencido por sus enemigos, aunque él iba desarmado. La narración fue recogida en España por Gil de Zamora, en el Prólogo del Liber Mariae.

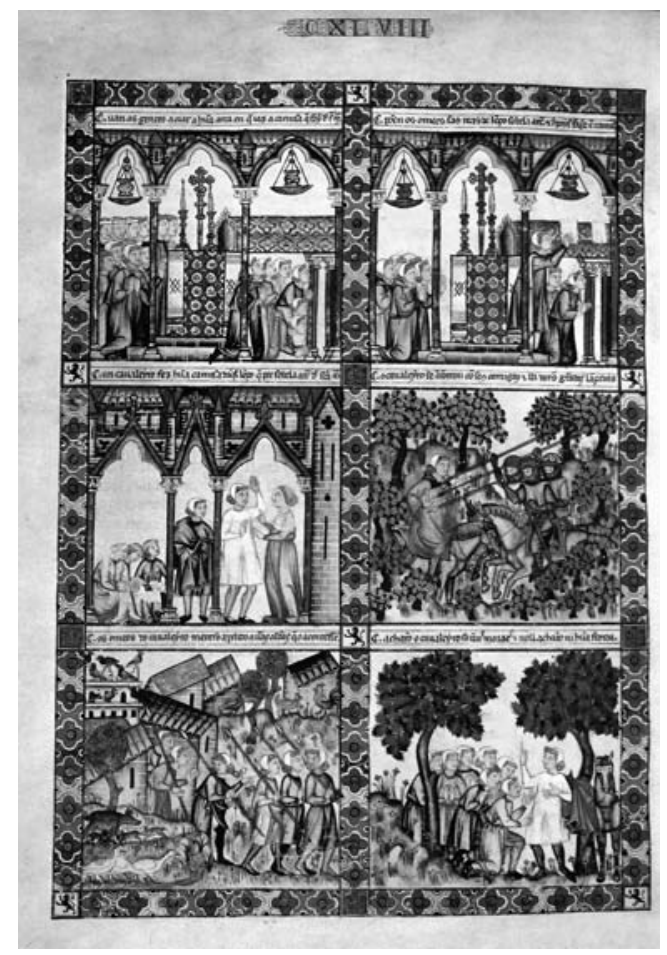

Fig. 5. CANTIGA 148 (Mss. El Escorial).

42 Le MARCHANT, J., Op. Cit., Miracle 21, «Dou cheualier qui fu sauue de mort a uie, porce quil auoit vestue (une) des chemises de Chartres", pp. 120-124. 


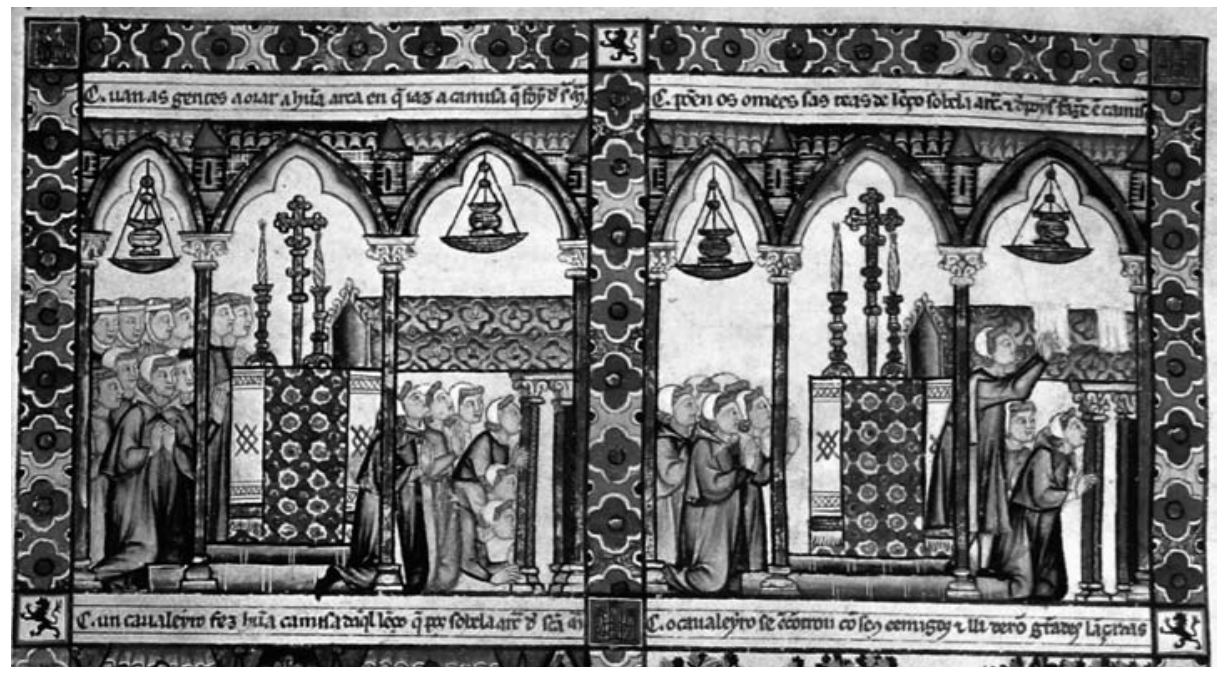

Fig. 6. Det. CANTIGA 148 (Mss. El Escorial).

El texto de la Cantiga dice así: «Y de esto un milagro mostraré de tal manera que será muy gran prueba de los otros de la Virgen; que hizo muchos en Chartres, por una camisa suya, y ya os dije otros, bien oísteis cuáles. // En Chartres hay un arca, que muchos van a ver, donde se guarda una camisa de lino que fue de Ella, y cada uno lleva su tela y va a ponerla sobre aquella camisa que está envuelta en cendales. // Y después hacen camisas, cada uno de su talla, y en las lides las traen para que Dios los libre del daño de sus enemigos; aunque esto han de hacerlo sin engaño, que si no, ya no les valdría nada. // Por lo cual, un caballero traía vestida una de éstas, porque tenía muchos enemigos, pero en la Virgen Santa confiaba y creía y no hacía hechos malos ni injustos. // Un día cabalgaba, cerca de un jaral, con su camisa vestida, que al armarse no la había olvidado; entonces sus enemigos le salieron al encuentro y le dieron muy grandes y mortales golpes. // Y cada uno de los que lo atacaban le daban tal golpe que le atravesaba el cuerpo con la lanza; pero le guardó la Virgen que no le llegaba ni un sólo golpe al cuerpo, ni le dejaban señales. // Y sus escuderos se fueron Ilorando hacia unas aldeas y dando gritos de llamada. Entonces muchas gentes se fueron llegando allí, y lo hallaron vivo al lado de unas moreras, // y les contó el hecho todo y de qué manera lo había guardado de la muerte la Señora verdadera; y además la camisa vieron toda entera, y loaron a la Virgen que milagros tales. // De muy grandes peligros e de muy grandes males guarda Santa María a los que le son leales» ${ }^{43}$.

43 ALFONSO X, EL SABIO, Cantigas de Santa María, Códice Rico de El Escorial versión de José Filgueira Valverde, Op. Cit., pp. 248-250.

En la ilustración de la misma a través de las miniaturas, la secuencia es la siguiente: a) Gentes orando ante el arca que contenía la camisa (velo) de la Virgen. El arca es de grandes dimensiones y está en alto sobre columnas. Sobre el altar dos candelabros y una gran cruz procesional, b) Cómo los hombres ponen las telas encima del arca y luego se hacen camisas cada uno de su talla, c) Cómo un caballero se pone la camisa, d) La camisa protege al caballero de las lanzas de los enemigos que le atraviesan sin he- 
En el entorno de la catedral se celebraban una serie de ferias. Las más importantes coincidían con las cuatro festividades de la Virgen: Anunciación, Natividad, Purificación y Asunción. Los peregrinos compraban recuerdos religiosos y objetos de devoción, lo que suponía una importante fuente de ingresos para la catedral. Los objetos devocionales eran, la mayoría de las veces, insignias de plomo de Nuestra Señora o de la sagrada túnica (velo) y los peregrinos más acaudalados gustaban de llevarse verdaderas camisolas, que, tras ser bendecidas por un sacerdote, se creía que eran beneficiosas para las futuras madres y protegían a los caballeros que las llevaban a las batallas bajo las armaduras

\section{EL CIRIO SALUTÍFERO}

Se reflejan aquí los efectos de una de las más graves epidemias que asoló la sociedad medieval, el ergotismo, y que no fue ajena al ámbito literario y artístico. Se trata, en realidad, de un mal producido por el cornezuelo del centeno; este cereal era el alimento básico de la población en aquel momento. La enfermedad debida a este parásito encontró entre la gente de condiciones de vida precarias y difíciles un terreno ideal para propagarse. Se conoce también como Mal des Ardents, Fuego de San Antón, Fuego Salvaje, Fuego Sagrado (Ignis Sacer), Fuego divino, de la Bienaventurada Virgen María, de San Fermín, o del Infierno, nombres diversos que se aplican según circunstancias y zonas. Numerosas han sido las ocasiones en que se ha representado bajo distintas formas, teniendo por intermediarios para obtener su curación a diferentes santos y, de modo especial, a la figura de María.

La terrible plaga apareció en Limoges, Aquitania, Turena y Borgoña. Era un fuego invisible que devoraba los miembros y los hacía caer a pedazos, ennegreciéndolos como el carbón, por lo que se decía que estaban consumidos por el fuego sagrado. Se trataba de una enfermedad pestilente que absorbía la carne, separándola de los huesos y producía un extremado ardor en las entrañas. A medida que avanzaba, el dolor y el ardor aumentaban y terminaban con la muerte que, a veces, se convertía en un largo proceso ya que no interesaba a los órganos vitales $^{44}$. La enfermedad afectó asimismo a Alemania, España y Sicilia, y numerosas iglesias de Flandes y Artois recibieron cirios a los que se conferían propiedades curativas.

Si San Marcial era el intercesor para esta enfermedad en la zona del Limousin, Santa Genoveva lo era en París, instituyendo Inocencio II en su honor, el día 26 de

rirle, e) Sus escuderos se van llorando hacia unas aldeas, dando gritos de llamada, f) Muchas gentes fueron allí y le hallaron vivo. El caballero se desnuda, les cuenta el hecho y deja ver su camisa. No tiene ninguna herida.

${ }_{44}$ MARTíN ANSÓN, Mํㅡ. L., «El Fuego de San Marcial y el Fuego de San Antón en el contexto del arte medieval», Anuario del Departamento de Historia y Teoría del Arte, Vol. 22 (2010), pp. 9-25. El tema aparece recogido, asimismo, en otras cantigas, pero aquí se hace entrega del cirio que será venerado como reliquia. 
noviembre de 1131, la fiesta del milagro de los ardientes, en recuerdo del milagro obtenido ${ }^{45}$. La epidemia sufrida en Paris se dice que causó 140.000 muertos. La arqueta con los restos de Santa Genoveva fue bajada del altar y llevada en procesión a la catedral. Antes de entrar en ella, se contó el número de enfermos y ascendía a 103. Al pasar bajo estas santas reliquias quedaron curados al instante, excepto tres incrédulos, cuya excepción sirvió para resaltar la gloria de la santa patrona de París ${ }^{46}$. El nombre de la iglesia de Notre Dame, situada frente a la catedral, fue cambiado hacia 1202, tomando el de Santa Genoveva de los Ardientes.

No obstante, se consideraba especialmente valiosa la intervención de María; así, en la Cantiga 91 se muestran agolpados en carros un buen número de enfermos afectados por el citado mal: «Esto sucedió en Francia, no ha mucho tiempo, que, por yerros que habían cometido, Dios les mandó para su castigo y confusión ese fuego que Ilaman de San Marcial. I/... Y era de tal naturaleza aquel mal, como he sabido, que primero les tomaba un frío, y después se quemaban peor que con fuego, y así sufrían de él todos con mortal cuita. // Porque los miembros se les caían y, de ninguna manera, podían comer ni dormir, ni sostenerse sobre los pies, y antes preferían ser muertos que sufrir tan descomunal dolor. // Por ende, una noche, sucedió que se les apareció una gran luz venida del cielo, y luego descendió Santa María, y la tierra tembló cuando llegó la Señora celestial. // Y los hombres tal miedo tomaron que se pusieron a huir, y no quedó, sino cuanto más pronto podían, y Ella hizo luego sanar a los enfermos, como Señora que no falta a sus cuitas...». Como se deduce tras la lectura, aquí el milagro se obra a través de la imagen, que cobra vida. Por ello nos vamos a centrar en el siguiente relato, en el que la presencia de la reliquia será de gran trascendencia.

Sin embargo, es en la Cantiga 259 (Códice de Florencia, fig. 7), donde interviene la Virgen dejando una candela, cuya valoración como reliquia atraerá a las multitudes. Observamos cómo enfermos por el Fuego de San Marcial son curados por un cirio salutífero que la Virgen entrega a unos juglares: Como Santa Maria fez aviir na ssa eigreja d'Arraz dous jograres que sse querian mal, e deu-lles hua candea que non pode outre trager senon eles ${ }^{47}$. Sin duda, se recoge aquí el conocido

45 ROUSSEL, R., Les pelerinages à travers les siècles, Paris 1954, p. 65.

46 Dom Jacques DUBOIS et BEAUMONT-MAILLET, L., Sainte Geneviève de Paris: la vie, le culte, l'art. Ed. Paris, 1982, p. 80. 33.

47 Alfonso o Sabio, Cantigas de Santa Maria. Ed. crítica de Walter METTMANN, Op. Cit., t. II, pp. 32-

Santa Maria punna d'aviir/os seus por se deles mellor servir

Dest' un miragre grande foi fazer / a Virgen, que vos Quero retraer, de dous lograres que fez ben querer; mas o demo provou de os partir. / Santa Maria punna d'aviir/os seus por se deles mellor servir

Ca pero se sabian miut'amar, / feze-os o demo assi gresgar / que ss' enviaron logo desfiar; / mas la Virgen non llo quis conssentir. / Estribillo.

Ca lles veo en sonnos e assi/ Iles dise': <Amigos, id' ambos a mi / a mia eigreja d'Arraz, e ali / vos direi como vos mando guarir.> / Estribillo

Cada un deles quando s'espertou / quanto lles ela disse lles nenbrou, / e foron y u lles ela mandou, / e virona escontra si viir. / Estribillo

E dii'; <Amigos, vossa entençon / partid', e ambos mui de coraçon / amade-mi e vos muit', e al non / façades, ca vos non ei de falir.> /. Estribillo 
como milagro de la Sainte Chandelle, guardada en la catedral de Arras, acaecido en la noche del miércoles 24 al jueves 25 de mayo de 1105.

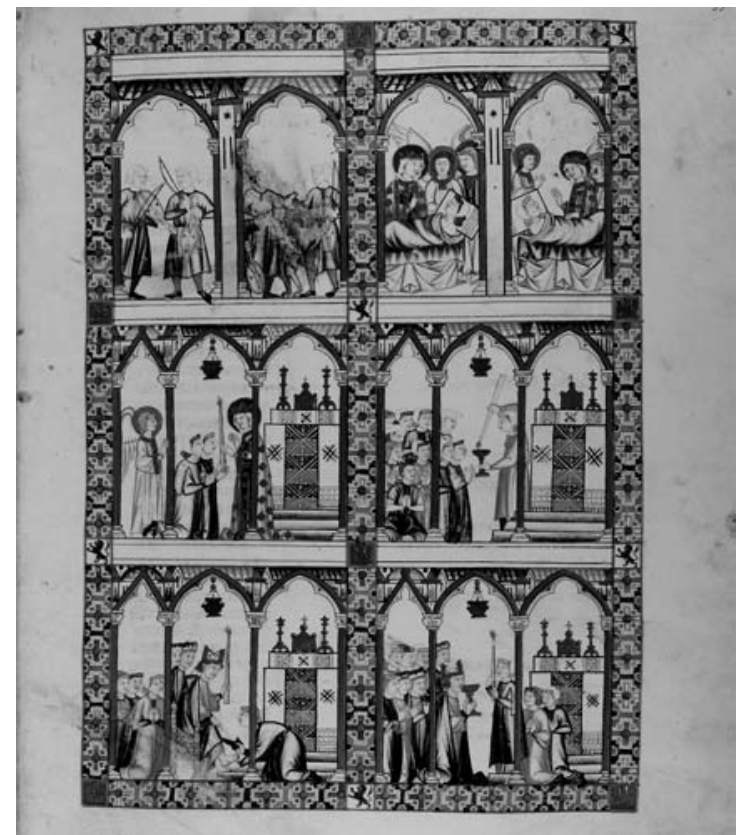

Fig. 7. CANTIGA 259 (Cod. Florencia).

Siguiendo el relato, a través de las distintas viñetas, observamos a los dos trovadores, Itier, de Tirlemont y Norman, del condado de Saint Pol, que estaban enfrentados porque uno había acusado al otro de la muerte de su hermano en un torneo (a). La Virgen se aparece a ambos, cuando una gran epidemia asolaba la ciudad, para anunciarles que iba a socorrer a su pueblo. Los dos reciben el mismo día, en lugares distintos, la visita de la Virgen, que les pide que vayan a Arras, junto al presbítero Lambert, a reconciliarse el uno con el otro y así recibir el medio para cuidar de los habitantes de Arras. Obedecen los dos, a pesar de sus diferencias, y se encuentran en la iglesia de Arras, donde esperan en oración (b). Hacia las tres de la mañana se despiertan por el canto de un gallo, seguido de una fuerte luz blanca. Una dama vestida de blanco, descendiendo de la bóveda, se dirige a

E deu-lles log' hua candea tal / con que ssaassen as gentes do mal / a que chaman fogo de San Marçal, / e saan quantos aló queren yr. / Estribillo.

Foron-s' ambos dali en grand' amor / e saavan as gentes da door, / como lles foi mandado da Señor / que nuca mentiu nen á de mentir. / Estribillo.

O bispo daquel logar lles fillou / a candea, mas mui mal baratou:/ ca o fogo no pe lle começou / e queria contra çima subir. / Estribillo

Quand' esto viu o bispo de mal sen, / pediu-lles daquela cera poren; e deron-lla a bever, e mui ben / lle fez o fogo logo del fogir. / Estribillo

Og' este dia esta vertud' an / os lograres da terra que y van, / e tan ben saan as gentes de pran, / que non an pois daquel mal a sentir. / Estribillo 
ellos. Sostiene en la mano una candela encendida que, según el relato, entrega a Lambert ${ }^{48}$. Sin embargo, aquí la entrega a los trovadores en presencia de un ángel (c). Les ordena verter unas gotas de cera en el agua y hacer beber a los enfermos esta mezcla para su curación del mal de San Marcial (d). El Obispo de aquel lugar les pidió la candela, pues comenzaba a sentir el «fuego» en un pie, (e) y le dieron de beber en una copa.

La reliquia de la Santa Candela se conserva en el tesoro de la catedral, en la abadía de St. Vaast y, según el Cartulaire de Notre Dame des Ardents ${ }^{49}$, la condesa Mafalda de Portugal, viuda de Felipe de Alsacia, hizo donación del estucherelicario que la guarda. Está realizado en plata nielada y datado a comienzos del siglo XIII. Tiene forma de cono muy alargado, de 62 centímetros de altura, dividido en dos partes distintas que encajan una en otra. A través de los vanos geminados, los fieles podían contemplar la Santa Candela. Fue restaurado en 1791 por un orfebre local y, después, en 1860 por el orfebre parisino A. Thiery. Al mismo tiempo que hacía fabricar el relicario, la condesa Mafalda ordenaba la erección de una nueva capilla, coronada por una elegante flecha o pirámide, construida sobre el propio modelo del relicario. Fue comenzada en 1200 y terminada en 1215, cuando se depositó allí el Santo Cirio. La capilla desapareció con la Revolución. Fue objeto de veneración desde la Edad Media y cada año, en el espacio de tiempo entre la celebración de la Ascensión y la de Pentecostés, período del aniversario del milagro, se presenta a los peregrinos.

Sin duda, la repercusión de la presencia de esta reliquia fue tan grande que la cera se convirtió en uno de los donativos preferidos por los enfermos para sus ofrendas, máxime, si, además, había una petición expresa de la propia Virgen. Así, en Le Livre des miracles de Notre Dame de Chartres, citado anteriormente, en el milagro $\mathrm{n}^{\circ} 32$, referido también a los afectados por el mal de los ardientes (Des ardans qui furent esteins par Nostre Dame et son enseignement) la Virgen anuncia que curará a todos los fieles que le hagan en Chartres una ofrenda de cera y, en

48 La catedral de Arras conserva un tríptico cuyo panel central representa a la Virgen que se dispone a enviar un cirio milagroso a los dos trovadores y al obispo Lambert. En primer plano, el obispo deja caer algunas gotas del cirio en el agua que uno de los músicos da de beber a los enfermos. Detrás, en el paisaje, está representada la zarza ardiente, tema a menudo asociado a la glorificación de la Virgen y quizás aquí, alusion al mal des ardents; alrededor del marco la inscripción: Buisson ardent, lumiére inextinguible. Las caras interiores de las alas muestran dos altares de la catedral reemplazados en 1740. TERNINCK, A., Essai historique et monographique sur l'ancienne cathedrale d'Arras, Arras, Brissy, 1853, pp. 45-49; Exposition retrospective des arts et monuments du Pas-de-Calais, Arras 1896, n 555; DRIMILLE, Guide de la cathedrale d'Arras, Arras 1913, pp. 55-56; LESTOCQUOY, J., «Quelques anges artisions du XIIle.siècle» en Monuments historiques de la France, t. V, fasc.1, 1959, pp. 31-34; Trésors des églises de France, exposition Paris 1965, n 33; Le Trésor de la Cathédrale d'Arras, Exposition au musée des Beaux Arts-Palais Saint Vaast, 31 août-13 octobre 1986, p. 23; «L'orfèvrerie à Arras aux XIV-XVe siècles», en Fragments d'un splendeur, exposition Arras, 2000, oㅜ 32, p. 97. Histoire d'un miracle, la sainte chandelle à Arras. Exposition, musée des Beaux Arts d'Arras du 9 avril au 4 juillet, 2005).

49 CAVROIS, L., Cartulaire de Notre Dame des Ardents, Arras, 1876, pp. 24-27. LINAS, Ch. de, Orfèvrerie du trezième siècle: la sainte chandelle d'Arras, Notice sur l'église d'Avesnes-le-Comte: diocèse d'Arras, 1856. 
efecto, doscientas sesenta personas debieron su curación al cumplimiento de este acto de devoción ${ }^{50}$.

\section{DUDA O INCREDULIDAD ANTE EL PODER DE LAS RELIQUIAS}

La historia que expone la Cantiga 61 (Mss. El Escorial, figs. 8 y 9): «Esta es cómo Santa María curó al que se le había torcido la boca porque renegara de Ella», pone de manifiesto otro aspecto del culto a las reliquias, que es el escepticismo o la incredulidad mostrada por el hombre ante un poder mágico o milagroso que le sobrepasa y, en ocasiones, le lleva a desdeñar no sólo las reliquias en sí sino también los santuarios donde reciben culto.

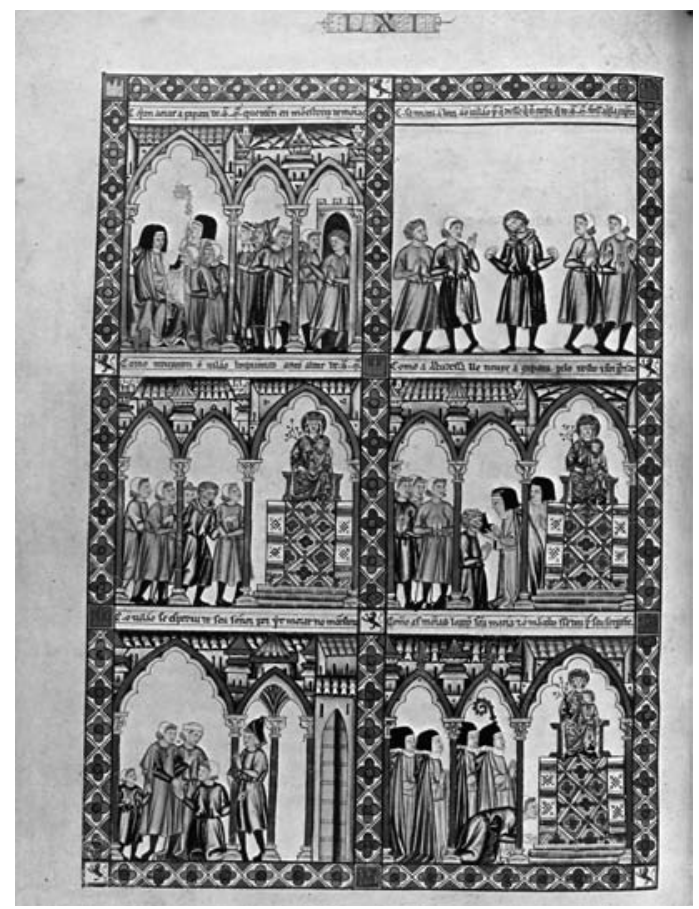

Fig. 8. CANTIGA 61 (Mss. El Escorial).

Esta Cantiga está relacionada con la veneración en Soissons del zapato de la Virgen que, se dice, fue ofrecido por Carlomagno al monasterio femenino de Notre Dame, donde su hermana Gisela fue abadesa. El origen de este culto hay que situarlo en un acontecimiento ocurrido en 1128, vinculado a la epidemia del Fuego Sagrado o mal de los ardientes, a que se ha hecho referencia en la Cantiga anterior. Estando al frente del convento la abadesa Matilde (†1143), una muchacha po-

50 Le Marchant, J., Op. Cit., pp. 205-210. 
bre tuvo los síntomas de la enfermedad; la abadesa hizo sobre ella la señal de la cruz con la reliquia, produciéndose la curación. Es la representación plástica que inicia el relato de las miniaturas.

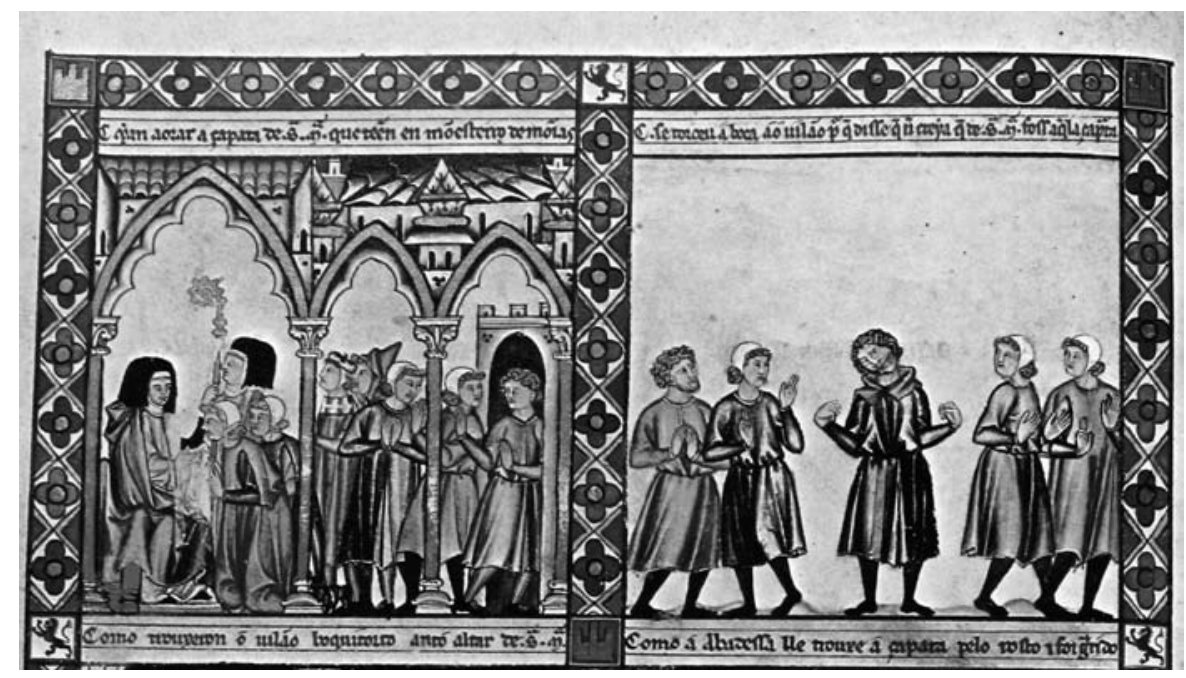

Fig. 9. Det. CANTIGA 61 (Mss. El Escorial).

La noticia del milagro se difundió y Hugo Farsito ${ }^{51}$, canónigo de Saint Jean les Vignes, en Soissons, compuso una serie de relatos de curaciones milagrosas en relación con esta enfermedad, que cifra en ciento tres, obtenidas por la intervención de un zapato de la Virgen. Sin embargo, curiosamente, no recoge ninguna tradición sobre la procedencia de la reliquia, tal vez teniendo en cuenta las críticas de Guibert de Nogent sobre la autenticidad de las reliquias, señalada con anterioridad. Retomada un siglo después, la versificación corresponde a Gautier de Coincy, en el relato Du bouvier puni et gari, y aparece recogida en el Liber Mariae de Gil de Zamora.

El zapato de la Virgen está en el centro de estos milagros, y parece deberse a la intervención de la abadesa Matilde la institución de un ritual que incluía una procesión por la iglesia con la reliquia. Esta impresión se apoya en la descripción de una curación milagrosa. Era costumbre que los enfermos, después de haber recuperado la salud, volviesen todas las mañanas a la iglesia, durante nueve días, en los que el zapato podía ser venerado y besado por cada uno de ellos. De tal modo, la zapatilla formaba parte de un ritual no sólo de curación, sino también de acción de gracias. Como en otros muchos santuarios, los peregrinos querían llevarse algún recuerdo que, por haber estado en contacto con la reliquia, les prote-

51 FARSITUS, H., Op. Cit., P. L. 179, cols. 1773-74. En especial los milagros; III, De puella sanata per soccum; V, De illa quae momordit soccum y XXXI, De quodam ab aegritudine pedis mirabiliter liberato.

COINCY, Gautier de, Op. Cit., pp. 190-244. 
giera y permitiera la curación de otras personas que no podían viajar hasta Soissons. En este caso solían ser piezas de madera, tierra o pan que hubieran tocado el zapato. No obstante, como es conocido, en numerosas ocasiones se producían verdaderos excesos. Así, Hugo Farsito revela el abuso de este ritual al relatar cómo una mujer que había recuperado la salud, besó la reliquia con tal celo que se apoderó de un trozo de ella con sus dientes. No entra en detalles sobre la intención de esta mujer, si deseaba ingerir un pedazo de ella o llevárselo para conservarlo. Este hecho llevó a la abadesa a retirar la preciosa reliquia de la circulación pública, teniendo que venerarla a distancia ${ }^{52}$.

Sin embargo, ya en su momento, no faltaron las críticas a esta reliquia. Había quien pensaba que si la Virgen iba calzada en vida podía haber sobrevivido uno de sus zapatos, mientras otros como Boso ${ }^{53}$, un sirviente que llegó a Soissons, intuía que un zapato real de la Virgen se habría deshecho en mil pedazos al cabo de tanto tiempo. Este es el episodio recogido en la Cantiga que nos ocupa.

En este caso el escéptico, después de arrepentido, va a Soissons donde obtiene el perdón: "Os diré de esto un milagro que sucedió en Soissons, donde hay un libro todo lleno de milagros de aquel lugar (porque no vino de fuera), que la Madre de Dios muestra noche y día. // Hay en aquel monasterio un zapato que fue de la Virgen a la que el mundo acude y de la que dijo un villano de mala conducta que él en aquello por nada creería. /l. Dijo él: Porque no es cosa fácil de creer, que habiendo pasado tanto tiempo, se conserve el zapato tan bien guardado, que ya no se hubiese podrido; esto no sería. // Diciendo esto, iba por un camino, él con otros cuatro, a una feria, y se le torció la boca de tal manera que quien quiera que lo viese, se espantaría. // Y tal dolor tenía, que creía que los ojos se le saltaban de la cabeza, y, con esta angustia, se volvía luego en romería, a donde el zapato estaba. // Y luego que llegó, se echó tendido en tierra, ante el altar, viéndose perdido, arrepintiéndose de haber sido tan atrevido en decir tan grande locura. // Entonces, la abadesa del monasterio le pasó el zapato por el rostro de su castigo, y se le tornó tan entero y tan sano como antes lo tenía. // Cuando el villano se sintió curado, se despidió del señor al que servía, y se vino luego al monasterio y allí es sirviente todavía ${ }^{54}$.

Multitud de enfermos y peregrinos llegaban a Soissons para venerar el Saint Soulier, circunstancia que, de algún modo, contribuyó a la creación de un nuevo hospital y una nueva iglesia. Hacia el año 1146, un niño, curado por la intervención del mismo, gritó que la Virgen María reclamaba una nueva iglesia, y la princesa

52 CLARK, A. L., "Guardians of the Sacred: The Nuns of Soissons and the Slipper of the Virgin Mary», Church History. Studies in Christianity and Culture, vol. 76, 4.

53 Cantigas de Alfonso X el Sabio, Ed. Jesús Montoya Martínez, 2005, p. 141, anota que Boso (en latín) o «Bausán», equivalente a «perverso, vil y traidor», es un término derivado del alemán bose. Migne, en la edición de Hugo Farsito, escribe y toma el vocablo como nombre propio. La Cantiga lo traduce como «vilâo de gran barata».

54 ALFONSO X EL SABIO, Cantigas de Santa María, Códice Rico de El Escorial versión de José Filgueira Valverde, Op. Cit. 
Matilde de Toulouse, que era abadesa de Notre Dame, decidió obedecer la orden del cielo, construyendo un edificio capaz de albergar la multitud de peregrinos, así como de guardar dignamente las reliquias que allí se adoraban. Todo ello no hubiera sido suficiente si la devoción de sus parientes y de su tío Luis VII, no hubiera aumentado los recursos del monasterio. En el plazo de quince o veinte años una iglesia nueva reemplazó a la antigua ${ }^{55}$.

Distintos zapatos de la Virgen se conservan en varios lugares; Saint Flour, el burgo de Saint Jacqueme en Saboya, Rodas, Notre Dame de Puy, etc. Todos estos zapatos habían calzado pies de tamaño diferente, si se juzga por su forma; pero, si se juzga desde la fe la cuestión es diferente. Curiosamente, los españoles debían a una revelación la medida del pie de la Virgen que, con arreglo a ello, debía ser pequeño y lindo. El papa Juan XXII acordó grandes indulgencias a los que besaran con devoción esta medida del pie de Nuestra Señora. La inquisición de Roma se vio obligada a suprimir esta práctica supersticiosa, el 23 de junio de 1635, sin respetar la decisión del Papa ${ }^{56}$.

\section{ALFONSO X VENERADOR DE RELIQUIAS}

Como no podía ser de otro modo, el monarca se sintió inmerso en esta cultura, de la que participó activamente, siendo él mismo «coleccionista» y devoto de reliquias, de modo muy especial de la Virgen. Así, en las Partidas nos recuerda que, junto a los restos de los santos, «sobre todas las otras reliquias son más de guardar las de nuestro señor Jesucristo e las de su madre santa María», y, además, "que todas estas reliquias deben tener en lugar limpio e muy honrado, e deben ser muy honradas e muy guardadas con cerradura, de tal manera que no las pueda ninguno hurtar ni tomar para haberlas, ni de otra guisa sin placer de aquellos lugares en que estuvieren por codicia de ganar algo con ellas, ni las vender...». Como puede observarse, incluso legisla contra los vicios más frecuentes, como son el hurto y la venta, recogiendo la acusación de simonía ${ }^{57}$.

${ }_{55}$ MARTIN, H., Histoire de Soissons depuis les temps les plus reculés jusqu'a nos tours. Paris, 1837, p. 39.

56 COLLIN de PLANCY, Jacques-Albin-Simon, Dictionnaire critique des reliques et des images miraculeuses, Paris, 1821, p. 171.

57 ALFONSO X, Las Siete Partidas, Op. Cit., Partida Primera, Título IV, Ley LXV. De las reliquias de los santos, cómo deben ser honradas e guardadas. Ornamentos llaman aquellas cosas preciadas que tiene santa Iglesia apuesta e honrada así como dice la ley ante de ésta. Pero aquello que mayor honra ahí hacen del cuerpo de nuestro señor Jesucristo a fuera son las reliquias de los santos cuyos cuerpos fueron canonizados, que quiere decir tanto como otorgados por santos. E esto no puede otro hacer si no la santa Iglesia de Roma. E sobre todas las otras reliquias son más de guardar las de nuestro señor Jesucristo e las de su madre santa María. E todas estas reliquias deben tener en lugar limpio e muy honrado, e deben ser muy honradas e muy guardadas con cerradura, de tal manera que no las pueda ninguno hurtar ni tomar para haberlas, ni de otra guisa sin placer de aquellos lugares en que estuvieren por codicia de ganar algo con ellas, ni las vender; que las santas cosas no las puede ninguno haber por precio e por eso no pueden ser vendidas, pues que por ellas no pueden dar cosas que tanto valen. E como quiera que las cosas temporales tanto vale la cosa como lo porque es vendida, esto no es en las espirituales donde cualquier que las vendiese pecarían mortalmente e haría simonía. P. 30. 
En la Cantiga 257 (Códice de Florencia fig. 10, det.): "Cómo Santa María protegió sus reliquias para que no se dañasen entre otras muchas que quedaron mal paradas " 58 , se pone de manifiesto la veneración de las reliquias por parte del Rey Sabio, quien, como corresponde a su siglo, fue un gran devoto de ellas. Así, se nos muestra en su alcázar sevillano, rodeado de su inmensa colección de relicarios, ocupado de guardarlos minuciosamente dentro de un cofre antes de abandonar la ciudad.

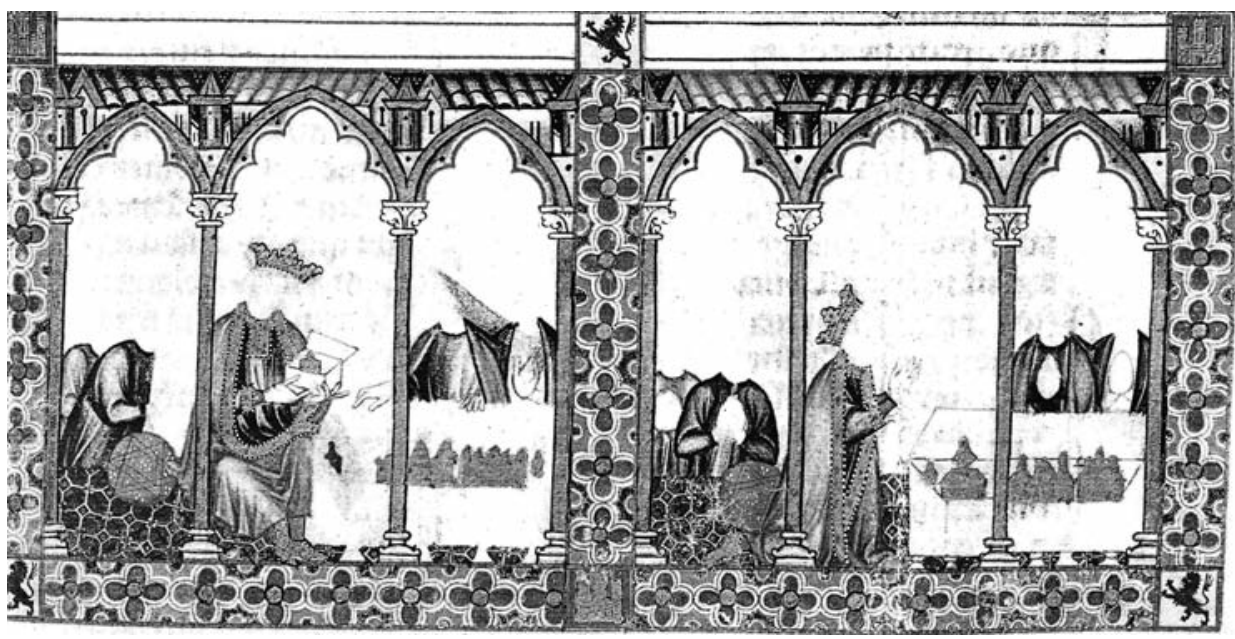

Fig. 10. CANTIGA 257 (Cod. Florencia).

En el relato en imágenes, en el que faltan algunas, se cuenta cómo Alfonso $X$ en Sevilla hizo guardar muchas reliquias de la Virgen y de los Santos y de las Santas (a, b. d). El rey se fue para Castilla y tardó diez años en volver a Sevilla. Cuando regresó halló que casi todas sus pertenencias se encontraban en un es-

58 “Como Santa Maria guardou sas relicas que se non danassen entr' outras, muitas que se danaron. Ben guarda Santa Maria pola sa vertude / sas relicas per que muitos receben saude. / Desto direi un miragre grand' a maravilla, / que al Rey Don Affonsso aveo. En Sevilla / foi guardar relicas da Madre de Deus e Filla / e de santos; e direi com', e Deus y m' ajude. Ben guarda Santa Maria pola sa vertude / sas relicas per que muitos receben saude. / As relicas eran muitas de Santa Maria / e de santos e de santas, por que Deus fazia / miragres; e el Rei ensserró-as aquel dia / e foi-ss' end', e nonas mandou catar amyude. Ben guarda Santa Maria pola sa vertude / sas relicas per que muitos receben saude. / Foi-ss' el Rey pera Castela u morou dez anos; / e pois vo a Sevilla, achou grandes danos / nas relicas, pero siian envoltas en panos; / mas a Virgen preciosa ao seu recude. / Ben guarda Santa Maria pola sa vertude / sas relicas per que muitos receben saude. Ben guarda Santa Maria pola sa vertude / sas relicas per que muitos receben saude. / Toda-las outras relicas achou mal danadas / e as arcas en que seyan mal desbaratadas; / mais as de Santa Maria eran ben guardadas, / ca o dano das sas cousas mui ben se sacude. / Ben guarda Santa Maria pola sa vertude / sas relicas per que muitos receben saude. Ben guarda Santa Maria pola sa vertude / sas relicas per que muitos receben saude. / Quand' aquesto viu el Rey Don Affonsso, loores / deu grandes a Jhesu-Cristo, Sennor dos sennores; / e ouve des i da Virgen tan grandes amores, / que cuido que o coraçon nunca ende mude. / Ben guarda Santa Maria pola sa vertude / sas relicas per que muitos receben saude». Edic.Walter Mettmann, Op. Cit., t. II, pp. 28-29. 
tado deplorable, destruidas o seriamente dañadas, y las arcas desbaratadas, a excepción de las reliquias de Santa María, que estaban bien guardadas (e). Cuando esto vio el Rey dio grandes loores a Jesucristo, Señor de Señores (f). Mandó entonces guardar las reliquias, que él siempre había amado más entre todas sus pertenencias, en un tríptico conocido como las Tablas Alfonsíes, conservado en el tesoro de la catedral de Sevilla ${ }^{59}$. Mencionado expresamente en las Cantigas, en el codicilo de su testamento, fechado en Sevilla el 10 de enero de 1284, expresa su voluntad: "si el nuestro cuerpo ouiere a seer enterrado en Seuilla, que sea y dada la nuestra tabla que fiziemos fazer con los reliquias, a onra de Santa Maria, (e) que la trayan en la procesión en las fiestas de Sancta María, e la pongan sobrel altar...» ${ }^{60}$.

El alma es de madera recubierta de láminas de plata dorada, oro, piedras preciosas y semipreciosas, camafeos y esmaltes. Alfonso $\mathrm{X}$ realizaría el encargo en 1274 , y su ejecución se ha relacionado con el maestro Jorge, orfebre toledano que trabajó para la Capilla Real de Sevilla, o bien con orfebres del círculo sevillano. Entre los numerosos relicarios que aparecen en las ilustraciones de las Cantigas, que suelen repetir modelos similares, ninguno se aproxima en su forma a la Tablas. No obstante, en el Códice de Florencia (Cantiga 304, fig. 11), en la descripción del suceso acaecido en el monasterio de Ribela, donde se representan numerosos objetos sobre el altar y en las credencias, puede identificarse, a través de sus medallones, el tríptico de las Tablas Alfonsíes cerradas. El conocimiento directo del miniaturista que ejecutó esta página entre 1280 y 1284, permite situar la ejecución del relicario en la década de 1274-84.

La decoración y la ubicación de las reliquias se organiza siguiendo patrones geométricos, donde la figura base es el cuadrado, inscribiendo formas lobuladas. En la parte externa, las escenas de la Anunciación y la Epifanía se combinan con placas troqueladas con escudos de Castilla y León, así como el águila de Suabia. Las anillas visibles en el borde superior, insertas en botones de plata dorada, que sustituyeron a las cabecitas de león con argollas en su boca, servían para pasar unas correas que, sujetas a los hombros del diácono, permitían su salida en las procesiones.

Al abrir las Tablas se pueden ver las reliquias con su correspondiente identificación, colocadas en cápsulas de plata bajo cristal de roca. El número total de huecos en que se alojan asciende a trescientos sesenta y dos, y las inscripciones son doscientas treinta y dos. El cuadrado central, que carece de reliquias, muestra sobre lámina de oro ocho cabujones con piedras semipreciosas y un gran camafeo de ágata bizantino, del siglo XI, con la Virgen Theotocos entre dos personajes identificados como San Gregorio Nacianceno y San Juan Crisóstomo, que le ofrecen un

59 LAGUNA PAUL, T., «Tablas Alfonsíes», Alfonso X el Sabio, Sala San Esteban. Murcia. 27 octubre 2009/31 enero 2010. pp. 638-639. Recoge bibliografía anterior.

60 GONZÁlEZ JIMÉNEZ, M. (Ed.), Diplomatario andaluz de Alfonso X, Sevilla, 1991, p. 559. 
rollo y un libro o un cofre. En origen, iba rodeado de perlas y piedras, que fueron sustituidas en el siglo XVII por piezas de plata y esmaltes. Otra serie de camafeos de diversas épocas se pueden observar en las puertas laterales, con representaciones de Adán y Eva y la dama del unicornio que simboliza a Cristo, en la puerta izquierda, y los renacentistas de la puerta derecha, de la Virgen con el Niño y la Duda de Santo Tomás. La reutilización de camafeos y otras piezas antiguas gozó de gran prestigio en las obras de orfebrería medievales, ya que es sobradamente conocida la fascinación que la Antigüedad ejercía en la Edad Media, siendo muy numerosos los ejemplos que se podrían citar.

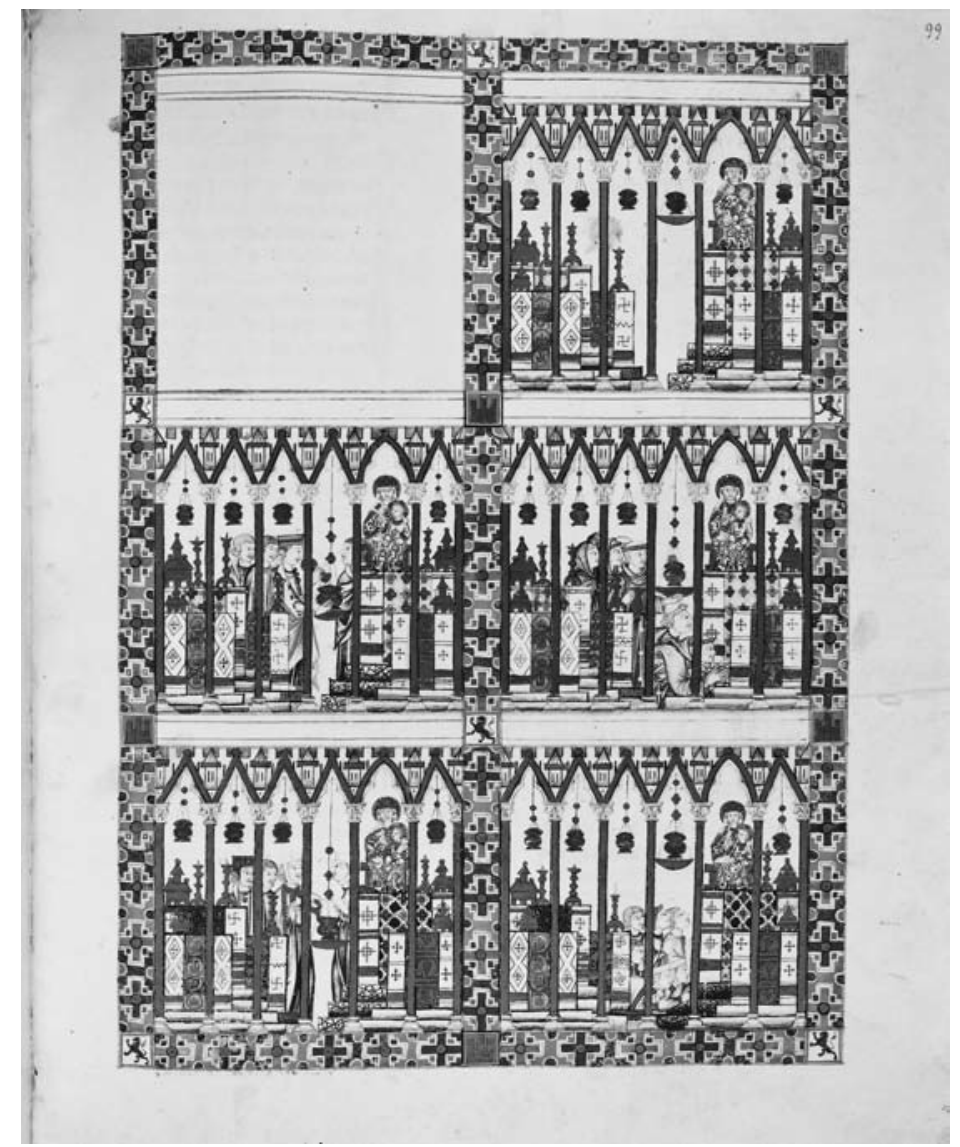

Fig. 11. CANTIGA 304 (Cod. Florencia).

Probablemente muchos de los relicarios, tan abundantes en las representaciones de las Cantigas y, que responden a formas habituales de la época, debieron pertenecer a la propia capilla del rey. De hecho, del codicilo del testamento, citado con anterioridad, se extrae, entre otras cosas, la existencia de otra tabla de reliquias: «la otra nuestra tabla con reliquias», que legaría a su heredero. No olvide- 
mos que las reliquias formaban parte consustancial de la vida de los monarcas. Estaban presentes en las ceremonias de coronación, mostrando la dimensión del poder real a partir de su doble naturaleza. Eran llevadas a los campos de batalla, y su presencia o la proximidad a los cuerpos santos era especialmente valorada cuando se sentía próxima la muerte, pues evitaban un posible ataque del demonio. San Juan Crisóstomo se expresa en este sentido: «los diablos huyen del lugar donde están enterrados los huesos de los mártires como del fuego o como de una tortura insufrible ${ }^{61}$ ».

61 BINSKI, Cf. P., Medieval Death. Ritual and Representation, Londres 1996, p. 18. 